\title{
Identification and Characterization of Rhizoctonia Species Associated with Soybean Seedling Disease
}

\author{
Olutoyosi O. Ajayi-Oyetunde and Carl A. Bradley, Department of Crop Sciences, University of Illinois, Urbana 61801
}

\begin{abstract}
In an effort to identify the Rhizoctonia spp. associated with seedling diseases of soybean, Rhizoctonia isolates were recovered from soybean seedlings with damping off and root and hypocotyl rot symptoms from Arkansas, Illinois, Kansas, Michigan, Minnesota, and the Canadian province of Ontario between 2012 and 2014. Based on cultural morphology, polymerase chain reaction restriction fragment length polymorphism, and phylogenetic analysis of the internal transcribed spacer (ITS) region of the ribosomal RNA genes, 80 isolates were confirmed to be Rhizoctonia solani, 24 were binucleate Rhizoctonia spp., and 10 were $R$. zeae. Of the 80 R. solani isolates, one belonged to anastomosis group (AG) 2-1, 52 belonged to AG-2-2IIIB, five belonged to AG-3 PT, three belonged to AG-4 HGI, two belonged to AG-4 HGIII, nine belonged to AG-7, and eight belonged to AG-11. Bayesian inference of

phylogeny using the ITS region revealed two clades of $R$. solani AG-7 that possibly correspond to different AG-7 subgroups. Phylogenetic analysis also provided evidence for genetic relatedness between certain binucleate $R$ hizoctonia and some $R$. solani isolates. On 'Williams 82' soybean, isolates of AG2-2IIIB were the most aggressive, followed by isolates of AG-7, AG-4, and AG-11. On 'Jubilee', a sweet corn cultivar, AG-2-2IIIB and AG-4 isolates caused significant stunting and root damage, whereas the damage caused by the AG-11 isolates was mostly restricted to the mesocotyl. Isolates of $R$. zeae and the binucleate Rhizoctonia spp. were not pathogenic on soybean or corn. Our results indicate that soybean and corn are hosts to the predominant and aggressive AG of $R$. solani, implying that rotation between these two crops may not be an effective management practice.
\end{abstract}

Seedling diseases have a history as a major constraint to soybean (Glycine $\max$ (L.) Merr.) production in North America. In the northcentral United States, the estimated impact of seedling diseases on soybean yields was first noted between 1989 and 1991 (Doupnik 1993), and between 2003 and 2005, a nationwide estimated suppression in yield was reported, with the greatest impact occurring in Illinois, Ohio, Minnesota, Kansas, and North Dakota (Wrather and Koenning 2006). From 2006 to 2009, seedling diseases ranked third among diseases and pests that reduced soybean yields in the United States and Canada (Koenning and Wrather 2010).

Among the myriad of plant pathogens associated with the seedling disease complex of soybean, Rhizoctonia solani (Kühn) (syn. Thanatephorus cucumeris (A. B. Frank) Donk) represents an important and intractable group. In addition to having a necrotrophic and saprophytic lifestyle, this plant pathogen exhibits significant genetic diversity, often evident as differences in colony morphology, biochemical and molecular properties, and pathogenicity on different hosts. As a consequence, members of this species complex have been classified into 14 anastomosis groups (AG) (AG 1 to13 and AG-BI) (Carling 1996; Carling et al. 1999; Ogoshi 1987), which are considered to be noninterbreeding populations (Anderson 1984) with distinct evolutionary origins (Vilgalys and Cubeta 1994). On the basis of characteristics other than hyphal fusion, several AG have been further divided into subgroups, with the exception of AG-2, which is subdivided on the basis of the frequency of fusion between isolates. Within AG-1, six subgroups (AG-1-1A, AG-1-1B, AG-1-1C, AG-1-1D, AG-1-1E, and AG-1-1F) have been identified (Kuninaga et al.

Present address of O. O. Ajayi-Oyetunde: Monsanto Company, Chesterfield, MO 63017.

Present address of C. A. Bradley: Department of Plant Pathology, University of Kentucky Research and Education Center, Princeton 42445.

Corresponding author: C. A. Bradley; E-mail: carl.bradley@uky.edu

Accepted for publication 26 November 2016.

() 2017 The American Phytopathological Society
2002; Ogoshi 1972; Parmeter et al. 1969; Priyatmojo et al. 2001; Richter and Schneider 1953; Watanabe and Matsuda 1966), and members of this AG can attack corn (Zea mays L.), soybean, bean (Phaseolus vulgaris L.), cabbage (Brassica oleracea L. Capitata group), lettuce (Lactuca sativa L.), and sorghum (Sorghum bicolor (L.) Moench) (Grosch et al. 2004; Herr 1992; Jones and Belmar 1989; Martin and Lucas 1984a; Mukou et al. 1975; Priyatmojo et al. 2001; Yang et al. 1990). Two subgroups are known within AG-2: AG-2-1 (crucifer type) and AG-2-2 (canker pathogen of sugar beet [Beta vulgaris L.] and carrot [Daucus carota L. subsp. sativus (Hoffm.) Arcang.]). AG-2-1 isolates are autotrophic for thiamine, while AG-2-2 isolates are thiamine auxotrophic (Ogoshi 1987). Three subgroups exist within AG-2-1: AG-2-1, AG-2t (tulip isolate), and AG-2Nt (tobacco isolate) (Kuninaga et al. 2000; Nicoletti et al. 1999; Schneider et al. 1997), while five subsets can be differentiated within AG-2-2: AG-2-2IIIB, AG-2-2IV, AG-2-2LP, AG-2-3, and AG-2-4 (Liu and Sinclair 1992; Stevens Johnk et al. 1993). Host crops of AG-2 include soybean, sugar beet, turf grass (tall fescue: Festuca arundinacea; creeping bent grass: Agrostis palustris), corn, canola (Brassica napus L.), wheat (Triticum aestivum L.), tulip (Tulipa gesneriana L.), and tomato (Lycopersicon esculentum Mill) (Dorrance et al. 2003; Engelkes and Windels 1996; Liu and Sinclair 1991; Misawa and Kuninaga 2010; Muyolo et al. 1993a; Nelson et al. 1996; Paulitz et al. 2006; Schneider et al. 1997; Sumner and Bell 1982; Watanabe and Matsuda 1966; Windels and Nabben 1989). Members of AG-3 are pathogens of solanaceous crops-tomato, tobacco (Nicotiana tabacum L.), and potato (Solanum tuberosum L.) (Meyer et al. 1990; Misawa and Kuninaga 2010; Nelson et al. 1996; Windels et al. 1997; Woodhall et al. 2007) —and three subgroups have been reported: AG-3 PT (potato type), AG-3 TB (tobacco type), and AG-3TM (tomato type) (Kuninaga et al. 2000, 2007; Ogoshi 1972; Parmeter et al. 1969; Richter and Schneider 1953; Stevens Johnk et al. 1993; Watanabe and Matsuda 1966). Three homogeneous groups (HG) have been identified in AG-4 (HG-I, HG-II, and HG-III), and host range of this AG include soybean, tomato, dry bean, cotton (Gossypium hirsutum L.), peanut (Arachis hypogaea L.), potato, melon (Cucumis melo L.), broccoli (B. oleracea L.), and spinach (Spinacia oleracea L.) (Balali et al. 1996; Brenneman 1996; Fenille et al. 2002; Kuramae et al. 2003; 
Muyolo et al. 1993b; Rothrock 1996; Windels and Nabben 1989). AG-5 isolates are associated with potato, turf grass, bean, soybean, and sugar beet (Balali et al. 1995; Martin and Lucas 1984a; Nelson et al. 1996; Windels et al. 1997). The nonpathogenic AG-6, which is mostly associated with mycorrhiza and orchid (Carling et al. 1999; Pope and Carter 2001), has been divided into two groups, the HG (HG-I) and isolates with remarkable genetic variation (Kuninaga and Yokosawa 1984). AG-8 isolates are pathogens of small grains, including barley (Hordeum vulgare L.) and wheat (Neate and Warcup 1985; Roberts and Sivasithamparam 1986), and they have been divided into at least five pectic zymogram groups (ZG): ZG1-1, ZG1-2, ZG1-4, ZG1-4, and ZG1-5 (MacNish and Sweetingham 1993). Two subgroups, thiamine prototrophic and thiamine auxotrophic, are evident in AG-9 (Carling and Kuninaga 1990), and potato, lettuce, and carrot are common hosts (Carling et al. 1987). Subgroups within AG-7 (host crops: soybean, potato, cotton, and water melon), AG-10 (nonpathogenic), AG-11 (host crops: cotton, wheat, soybean, potato, lupine [Lupinus luteus L.], and radish [Raphanus sativus L.]) (Carling et al. 1994; Kumar et al.1999), AG-12 (host crops: mycorrhiza [Mycorrhiza], orchid [family Orchidaceae], radish, and cauliflower [B. oleracea L. Botrytis group]) (Carling et al. 1999; Pope and Carter 2001), AG-13 (nonpathogenic), and AG-BI (nonpathogenic) have not been reported.

Around the globe, isolates of the subgroup AG-2-2IIIB (Fenille et al. 2002; Liu and Sinclair 1991; Muyolo et al. 1993a; Sneh et al. 1991) and of those of AG-4 (Bolkan and Ribeiro 1985; Fenille et al. 2002; Muyolo et al. 1993a; Nelson et al. 1996; Ploetz et al. 1985; Rizvi and Yang 1996; Zhao et al. 2005) and AG-5 (Nelson et al. 1996) have been identified as the major culprits causing seedling diseases of soybean. Other less aggressive $A G$ associated with soybean seedling diseases include AG-3 (Nelson et al. 1996), AG-7 (Baird et al. 1996; Rothrock et al. 1993), and AG-11 (Carling et al. 1994).

In the United States, Rhizoctonia root and hypocotyl rot is an important seedling disease of soybean, especially in the north-central region (Doupnik 1993), where more than $80 \%$ of the total U.S. soybean production occurs (American Soybean Association 2015). Reports of Rhizoctonia root rot epidemics on soybean first emerged during the 1967 growing season in Iowa, where a reduction in stand was observed (Tachibana 1968). In 1971, as high as a $48 \%$ reduction in yield was reported in small research plots (Tachibana et al. 1971). Causal AG or species of Rhizoctonia were unknown at the time the epidemic occurred; however, in 1996, Rizvi and Yang (1996) identified AG-2-2 and AG-4 isolates as the primary AG of $R$. solani associated with soybean seedling disease in Iowa. In 1993, Rothrock et al. (1993) reported the occurrence of AG-7 isolates on soybean seedlings from field sites at Colt, AR. A survey of the prevalent species of Rhizoctonia that attack soybean also was conducted in Ohio (Muyolo et al. 1993a), the Red River Valley of Minnesota and North Dakota (Nelson et al. 1996), and the Canadian province of Ontario (Zhao et al. 2005). Given that the population of $R$. solani affecting soybean seedlings in other major soybean-producing states in the United States has not been extensively investigated, information regarding pathogen variability and distribution across the country is scarce. Cropping systems differ across soybean-growing locations, and these differences can significantly enhance the prevalence of certain species of Rhizoctonia over others (Garbeva et al. 2006; Gudmestad et al. 1989; Hua et al. 2014). Moreover, $R$. solani AG and subgroups differ not only in their aggressiveness on specific host crops but also in their sensitivity to different fungicide seed treatments (Barnes et al. 1990; Carling et al. 1990; Kataria et al. 1991; Martin et al. 1984b). Therefore, information on the predominant groups, together with knowledge of their pathogenicity on soybean, is needed for making sound disease management decisions.

Illinois is a leading producer of soybean in the United States; unfortunately, a statewide investigation of the predominant Rhizoctonia spp. causing soybean seedling diseases has not been carried out to date. In the early 1990 s, two highly aggressive AG 2-2 isolates, 61D-3 and $65 \mathrm{~L}-2$, were recovered from diseased soybean plants collected from a soybean breeding plot at the University of Illinois (Liu and Sinclair 1991) but nothing is known about the variability in the AG associated with Rhizoctonia root and hypocotyl rot of soybean in the state. Similarly, the diversity of Rhizoctonia spp. associated with soybean seedling diseases in Arkansas, Michigan, and Kansas is unknown. Therefore, the objectives of this study were to (i) identify and characterize the species of Rhizoctonia associated with soybean seedling disease in Illinois, Arkansas, Michigan, and Kansas; (ii) determine whether there has been a change in the AG of $R$. solani that damage soybean seedlings in Minnesota and in Ontario, Canada; and (iii) determine the pathogenicity of the isolates recovered from Illinois on soybean and corn.

\section{Materials and Methods}

Isolate collection and storage. Soybean seedlings showing hypocotyl and root rot symptoms typical of $R$. solani infections were collected from 13 Illinois counties in 2012, 2013, and 2014 (Table 1). Plants were dug carefully to minimize root damage, then placed in sealed plastic bags and placed in a cooler during transport back to the lab, where they were stored overnight at $4^{\circ} \mathrm{C}$. Roots of plants were washed under running tap water to remove soil particles. Plants were then disinfected in $1 \% \mathrm{NaOCl}$ solution for $30 \mathrm{~s}$, followed by a thorough rinse in distilled water for $1 \mathrm{~min}$. Cut sections of about $3 \mathrm{~mm}$ in length from symptomatic plants were gently pressed onto solidified Ko and Hora medium (Ko and Hora 1971) and incubated in the dark at $25^{\circ} \mathrm{C}$ for 24 to $48 \mathrm{~h}$. Hyphal tips from colonies with right-angled branches typical of Rhizoctonia-like fungi were transferred to potato dextrose agar (PDA; Becton, Dickson and Company, Sparks, MD) amended with rifampicin at $25 \mathrm{mg} /$ liter and were incubated under light at $25^{\circ} \mathrm{C}$. Isolates recovered from Arkansas, Kansas, Michigan, Minnesota, and Ontario were collected as part of a multistate research project by the laboratories of Dr. Craig Rothrock (University of Arkansas, Fayetteville), Dr. Christopher Little (Kansas State University, Manhattan), Dr. Martin Chilvers (Michigan State University, East Lansing), Dr. Dean Malvick (University of Minnesota, St. Paul), and Mr. Albert Tenuta (Ontario Ministry of Agriculture and Rural Affairs, Ridgetown, ON, Canada), respectively. These isolates were then sent to Dr. Ahmad Fakhoury's laboratory (Southern Illinois University, Carbondale), where they will continue to be curated as part of the multistate research project. Tester isolates of $R$. solani used for identification of AG and their respective sources are listed in Table 2. All isolates were maintained on sterile table beet seed. These were dried under a sterile flow hood for $48 \mathrm{~h}$, placed in 2.0-ml Nalgene cryogenic vials (Sigma-Aldrich, St. Louis), and stored at $4^{\circ} \mathrm{C}$. For long-term storage, three plugs $(5 \mathrm{~mm}$ in diameter) of isolates on PDA were placed in $1.5-\mathrm{ml}$ microcentrifuge tubes containing $850 \mu \mathrm{l}$ of $15 \%$ glycerol and maintained at $-80^{\circ} \mathrm{C}$

Morphological characterization and AG typing of isolates. All isolates were characterized based on cultural morphology, cellular nuclei number in young vegetative hyphae, and anastomosis reactions with tester isolates. Cultural characteristics were determined by growing each isolate on PDA and incubating at $25^{\circ} \mathrm{C}$ for 14 days. Isolates identified as members of AG-2-2 were further maintained at $35^{\circ} \mathrm{C}$ to enable rapid delineation of the AG-2-2IIIB isolates (Sneh et al. 1991). Cultures were examined for colony color, sclerotia formation and color, aerial mycelia formation, and growth zonation at 5 and 14 days after plating. Binucleate Rhizoctonia (BR) were differentiated from multinucleate Rhizoctonia by an examination of the nuclear condition using the Safranin O staining technique (Bandoni 1979; Yamamoto and Uchida 1982).

For AG determination, a modified version of the clean slide technique (Kronland and Stanghellini 1988) coupled with Safranin O staining was used for observing hyphal fusion reactions between testers and unknown isolates. Briefly, the unknown isolates and testers initially were grown on PDA for 3 to 5 days. Plugs ( $5 \mathrm{~mm}$ in diameter) of the unknown isolates were cut from the growing edge of the plate and transferred to the opposite ends of a 100-by-15-mm petri dish containing $1.5 \%$ water agar. A $5-\mathrm{mm}$ plug of the tester isolate was placed about $4 \mathrm{~cm}$ away from the unknown isolate and incubated at $25^{\circ} \mathrm{C}$ for 24 to $72 \mathrm{~h}$, depending on the growth of the interacting isolates. Cut sections of overlapping hyphae were placed on a plain microscope glass slide, stained with safranin $\mathrm{O}$ and $3 \% \mathrm{KOH}$, and covered with a coverslip before viewing under a compound microscope. Reaction types observed between interacting hyphae were assigned to one of the four categories $(\mathrm{C} 0, \mathrm{C} 1, \mathrm{C} 2$, or $\mathrm{C} 3)$ described by Carling et al. (1988) (Fig. 1). In the $\mathrm{C} 0$ reaction type, interaction or contact between hyphae of paired isolates is nonevident. Isolates 
exhibiting such reaction types are said to be genetically different and belong to different AG. For the $\mathrm{C} 1$ reaction, cell wall contact between hyphae of paired isolates is occasionally observed; however, contact between cell membranes does not occur, and the death of anastomosing cells may or may not be observed. This form of reaction is mostly observed among distantly related isolates belonging to the same or different AG. For genetically distinct isolates within the same AG, cell wall fusion and the death of anastomosing and adjacent cells, otherwise referred to as the "killing reaction" (Flentje et al. 1967), are usually apparent; a characteristic feature defining the $\mathrm{C} 2$ reaction type. The last reaction type, C3, is characterized by a perfect fusion of cell walls and cell membranes of paired isolates and by an absence of

Table 1. Origin, year of isolation, and identification method used for the isolates of Rhizoctonia collected from soybean in Arkansas, Illinois, Kansas, Michigan, Minnesota, and Ontario

\begin{tabular}{|c|c|c|c|c|c|}
\hline Isolate ID & GenBank $^{\mathbf{a}}$ & Year & County, state & Rhizoctonia spp. $^{\mathbf{b}}$ & Identification method \\
\hline$\overline{\text { S_P_19a }}$ & KX118381 & 2013 & Pike Co., IL & AG-11 & ITS, PCR-RFLP \\
\hline S_P_19b & KX118382 & 2013 & Pike Co., IL & AG-11 & ITS, PCR-RFLP \\
\hline $\mathrm{K} \_4 \_18 \mathrm{~b}$ & KX118367 & 2013 & St. Clair Co., IL & AG-11 & ITS, PCR-RFLP \\
\hline BVT_18 & KX118336 & 2013 & St. Clair Co., IL & AG-11 & ITS, PCR-RFLP \\
\hline $\mathrm{X} 12 \mathrm{SDSa}$ & KX118394 & 2013 & Illinois & AG-11 & ITS, PCR-RFLP \\
\hline K_ARSO2_1_11 & KX118356 & 2013 & Arkansas & AG-11 & ITS, PCR-RFLP \\
\hline K_ARSO2_1_20 & KX118358 & 2013 & Arkansas & AG-11 & ITS, PCR-RFLP \\
\hline K_ARSO2_5_1 & KX118363 & 2013 & Arkansas & AG-2-1 & ITS, PCR-RFLP \\
\hline DK_11 & KX118344 & 2013 & DeKalb Co., IL & AG-2-2IIIB & ITS, PCR-RFLP \\
\hline DK_8 & KX118345 & 2013 & DeKalb Co., IL & AG-2-2IIIB & ITS, PCR-RFLP \\
\hline X42210_b & KX118397 & 2013 & Illinois & AG-2-2IIIB & ITS, PCR-RFLP \\
\hline ER_15 & KX118346 & 2013 & Whiteside Co., IL & AG-2-2IIIB & ITS, PCR-RFLP \\
\hline ER_19a & KX118347 & 2013 & Whiteside Co., IL & AG-2-2IIIB & ITS, PCR-RFLP \\
\hline ER_19b & KX118348 & 2013 & Whiteside Co., IL & AG-2-2IIIB & ITS, PCR-RFLP \\
\hline ER_2 & KX118349 & 2013 & Whiteside Co., IL & AG-2-2IIIB & ITS, PCR-RFLP \\
\hline ER_4 & KX118350 & 2013 & Whiteside Co., IL & AG-2-2IIIB & ITS, PCR-RFLP \\
\hline X12RS41 & KX118392 & 2012 & Williamson Co., IL & AG-2-2IIIB & ITS, PCR-RFLP \\
\hline ONSO2_18 & KX118372 & 2012 & Ontario & AG-2-2IIIB & ITS, PCR-RFLP \\
\hline WONS $13 \_8 \_5$ & KX118391 & 2013 & Ontario & AG-2-2IIIB & ITS, PCR-RFLP \\
\hline WONS 13_12_3 & KX118390 & 2013 & Ontario & AG-2-2IIIB & ITS, PCR-RFLP \\
\hline PDONS 13_8_1 & KX118373 & 2013 & Ontario & AG-2-2IIIB & ITS, PCR-RFLP \\
\hline X248_3b KH & KX118396 & 2012 & Jackson Co., IL & AG-3PT & ITS \\
\hline C_far_500_10a & KX118341 & 2013 & Champaign Co., IL & AG-3PT & ITS \\
\hline C_far_500_3 & KX118342 & 2013 & Champaign Co., IL & AG-3PT & ITS \\
\hline C_far_500_6 & KX118343 & 2013 & Champaign Co., IL & AG-3PT & ITS \\
\hline C_far_500_1 & KX118340 & 2013 & Champaign Co., IL & AG-3PT & ITS \\
\hline EV_3 & KX118352 & 2013 & Jackson Co., IL & AG-4 HGI & ITS, PCR-RFLP \\
\hline EV_6 & KX118353 & 2013 & Jackson Co., IL & AG-4 HGI & ITS, PCR-RFLP \\
\hline BVT_28 & KX118338 & 2013 & St. Clair Co., IL & AG-4 HGIII & ITS, PCR-RFLP \\
\hline BVT_3 & KX118339 & 2013 & St. Clair Co., IL & AG-4 HGIII & ITS, PCR-RFLP \\
\hline EV_19 & KX118351 & 2013 & Jackson Co., IL & AG-7 & ITS \\
\hline EV_7 & KX118354 & 2013 & Jackson Co., IL & AG-7 & ITS \\
\hline BVT_16 & KX118335 & 2013 & St. Clair Co., IL & AG-7 & ITS \\
\hline BVT_20 & KX118337 & 2013 & St. Clair Co., IL & AG-7 & ITS \\
\hline K_ARSO2_1_6 & KX118359 & 2013 & Arkansas & AG-7 & ITS, PCR-RFLP \\
\hline K_ARSO2_1_8 & KX118360 & 2013 & Arkansas & AG-7 & ITS, PCR-RFLP \\
\hline $\mathrm{K} \_\mathrm{ARSO} 2 \_2 \_5$ & KX118362 & 2013 & Arkansas & AG-7 & ITS, PCR-RFLP \\
\hline K_ARSO2_1_9 & KX118361 & 2013 & Arkansas & AG-7 & ITS, PCR-RFLP \\
\hline $\mathrm{K} \_2 \_1 \mathrm{a}$ & KX118366 & 2013 & Gallatin Co., IL & Ceratobasidium sp. & ITS, CNN \\
\hline S_P_18a & KX118378 & 2013 & Pike Co., IL & Ceratobasidium sp. & ITS, CNN \\
\hline S_P_18b & KX118379 & 2013 & Pike Co., IL & Ceratobasidium sp. & ITS, CNN \\
\hline S_P_18c & KX118380 & 2013 & Pike Co., IL & Ceratobasidium sp. & ITS, CNN \\
\hline S_P_2 & KX118383 & 2013 & Pike Co., IL & Ceratobasidium sp. & ITS, CNN \\
\hline K_1_24c & KX118365 & 2013 & Pope Co., IL & Ceratobasidium sp. & ITS, CNN \\
\hline $\mathrm{X} 12 \mathrm{SDSb}$ & KX118395 & 2013 & Illinois & Ceratobasidium sp. & ITS, CNN \\
\hline X4SDS & KX118398 & 2013 & Illinois & Ceratobasidium sp. & ITS, CNN \\
\hline X9SDS & KX118399 & 2013 & Illinois & Ceratobasidium sp. & ITS, CNN \\
\hline$m \_24 \_b$ & KX118370 & 2012 & Whiteside Co., IL & Ceratobasidium sp. & ITS, CNN \\
\hline m_24_c & KX118371 & 2012 & Whiteside Co., IL & Ceratobasidium sp. & ITS, CNN \\
\hline K_ARSO2_1_19 & KX118357 & 2013 & Arkansas & Ceratobasidium sp. & ITS, CNN \\
\hline K_ARSO2_5_20 & KX118364 & 2013 & Arkansas & Ceratobasidium sp. & ITS, CNN \\
\hline WMIS02_6_19 & KX118389 & 2013 & Michigan & Ceratobasidium sp. & ITS, CNN \\
\hline MNSO1_3_14 & KX118369 & 2012 & Minnesota & Ceratobasidium sp. & ITS, CNN \\
\hline $\mathrm{X} 12 \mathrm{RS} 42$ & KX118393 & 2012 & Champaign Co., IL & Ceratobasidium sp. & $\begin{array}{l}\text { ITS, CNN } \\
\text { (continued on next page) }\end{array}$ \\
\hline
\end{tabular}

${ }^{\mathrm{a}}$ GenBank accession number; NA = not applicable.

${ }^{\mathrm{b}} \mathrm{AG}=$ anastomosis group.

${ }^{\mathrm{c}}$ ITS $=$ internal transcribed spacer region of the ribosomal DNA, PCR-RFLP $=$ polymerase chain reaction restriction fragment length polymorphism analysis of the amplified ribosomal DNA, CNN = cellular nuclear number, and $\mathrm{M}=$ morphological identification on culture media. 
dead anastomosing and adjacent cells. This is commonly observed during self-anastomosis as well as during fusion among clones. Pairing for each unknown isolate was replicated twice, and at least four anastomosing points were required for a definitive placement of an unknown isolate in an AG. Pictures of cellular nuclear number and anastomosis reaction types were taken with a Zeiss Axiocam ERc5s and viewed via a Zeiss ZEN imaging software attached to a PC.
DNA isolation, polymerase chain reaction restriction fragment length polymorphism analysis of the ribosomal DNA internal transcribed spacer regions, and polymerase chain reaction analysis with AG-specific primers for AG typing of $\boldsymbol{R}$. solani isolates. For genomic DNA extraction, each isolate was grown on potato dextrose broth (Becton, Dickson and Company) and incubated in continuous light without shaking at $25^{\circ} \mathrm{C}$. Mycelia were harvested after

Table 1. (continued from preceding page)

\begin{tabular}{|c|c|c|c|c|c|}
\hline Isolate ID & GenBank $^{a}$ & Year & County, state & Rhizoctonia spp. ${ }^{\mathbf{b}}$ & Identification method ${ }^{\mathrm{c}}$ \\
\hline W2_1_12 & KX118387 & 2013 & Pope Co., IL & R. zeae & ITS, M \\
\hline W2_2_12 & KX118388 & 2013 & Pope Co., IL & R. zeae & ITS, M \\
\hline Maxwell 1_1_KH & KX118368 & 2012 & Sangamon Co., IL & R. zeae & ITS, M \\
\hline 12RS52 & NA & 2012 & Jackson Co., IL & AG-11 & PCR-RFLP \\
\hline IL $2014 \mathrm{a}$ & NA & 2014 & Champaign Co., IL & AG-2-2IIIB & PCR-RFLP \\
\hline DK_10 & NA & 2013 & DeKalb Co., IL & AG-2-2IIIB & PCR-RFLP \\
\hline DK_13 & NA & 2013 & DeKalb Co., IL & AG-2-2IIIB & PCR-RFLP \\
\hline DK_14 & NA & 2013 & DeKalb Co., IL & AG-2-2IIIB & PCR-RFLP \\
\hline DK_15a & NA & 2013 & DeKalb Co., IL & AG-2-2IIIB & PCR-RFLP \\
\hline DK_15b & NA & 2013 & DeKalb Co., IL & AG-2-2IIIB & PCR-RFLP \\
\hline DK_16 & NA & 2013 & DeKalb Co., IL & AG-2-2IIIB & PCR-RFLP \\
\hline DK_19 & NA & 2013 & DeKalb Co., IL & AG-2-2IIIB & PCR-RFLP \\
\hline DK_3a & NA & 2013 & DeKalb Co., IL & AG-2-2IIIB & PCR-RFLP \\
\hline DK_3b & NA & 2013 & DeKalb Co., IL & AG-2-2IIIB & PCR-RFLP \\
\hline DK_4a & NA & 2013 & DeKalb Co., IL & AG-2-2IIIB & PCR-RFLP \\
\hline DK_4b & NA & 2013 & DeKalb Co., IL & AG-2-2IIIB & PCR-RFLP \\
\hline DK_6a & NA & 2013 & DeKalb Co., IL & AG-2-2IIIB & PCR-RFLP \\
\hline DK_6b & NA & 2013 & DeKalb Co., IL & AG-2-2IIIB & PCR-RFLP \\
\hline DK_7 & NA & 2013 & DeKalb Co., IL & AG-2-2IIIB & PCR-RFLP \\
\hline X42210_c & NA & 2013 & Illinois & AG-2-2IIIB & PCR-RFLP \\
\hline X42304_b & NA & 2013 & Illinois & AG-2-2IIIB & PCR-RFLP \\
\hline X42304_g & NA & 2013 & Illinois & AG-2-2IIIB & PCR-RFLP \\
\hline K_IL_SO2_3_25c & NA & 2013 & Warren Co., IL & AG-2-2IIIB & PCR-RFLP \\
\hline ONSO2_17 & NA & 2012 & Ontario & AG-2-2IIIB & PCR-RFLP \\
\hline ONSO2_16 & NA & 2012 & Ontario & AG-2-2IIIB & PCR-RFLP \\
\hline ONSO2_14 & NA & 2012 & Ontario & AG-2-2IIIB & PCR-RFLP \\
\hline ONSO2_13 & NA & 2012 & Ontario & AG-2-2IIIB & PCR-RFLP \\
\hline ONSO2_15 & NA & 2012 & Ontario & AG-2-2IIIB & PCR-RFLP \\
\hline WONS 13_8_4 & NA & 2013 & Ontario & AG-2-2IIIB & PCR-RFLP \\
\hline WONS 13_8_2 & NA & 2013 & Ontario & AG-2-2IIIB & PCR-RFLP \\
\hline WONS 13_8_6 & NA & 2013 & Ontario & AG-2-2IIIB & PCR-RFLP \\
\hline PDONS 13_8_4 & NA & 2013 & Ontario & AG-2-2IIIB & PCR-RFLP \\
\hline PDONS 13_8_5 & NA & 2013 & Ontario & AG-2-2IIIB & PCR-RFLP \\
\hline PDONS 13_8_6 & NA & 2013 & Ontario & AG-2-2IIIB & PCR-RFLP \\
\hline PDONS 13_8_3 & NA & 2013 & Ontario & AG-2-2IIIB & PCR-RFLP \\
\hline PDONS 13_8_7 & NA & 2013 & Ontario & AG-2-2IIIB & PCR-RFLP \\
\hline PDONS 13_8_8 & NA & 2013 & Ontario & AG-2-2IIIB & PCR-RFLP \\
\hline WONS 13_8_8 & NA & 2013 & Ontario & AG-2-2IIIB & PCR-RFLP \\
\hline WONS 13_8_3 & NA & 2013 & Ontario & AG-2-2IIIB & PCR-RFLP \\
\hline WONS 13_8_7 & NA & 2013 & Ontario & AG-2-2IIIB & PCR-RFLP \\
\hline WONS 13_8_1 & NA & 2013 & Ontario & AG-2-2IIIB & PCR-RFLP \\
\hline PDONS 13_12_3 & NA & 2013 & Ontario & AG-2-2IIIB & PCR-RFLP \\
\hline WONS 13_8_4 & NA & 2013 & Ontario & AG-2-2IIIB & PCR-RFLP \\
\hline BVT_11 & NA & 2013 & St. Clair Co., IL & AG-4 HGI & PCR-RFLP \\
\hline K_ARSO2_1_7 & NA & 2013 & Arkansas & AG-7 & PCR-RFLP \\
\hline W_2_2_15 & NA & 2013 & Gallatin Co., IL & Ceratobasidium sp. & $\mathrm{CNN}$ \\
\hline W2_2_20 & NA & 2013 & Gallatin Co., IL & Ceratobasidium sp. & CNN \\
\hline NBK_IL_3 & NA & 2013 & Sangamon Co., IL & Ceratobasidium sp. & CNN \\
\hline NBK_IL_5 & NA & 2013 & Sangamon Co., IL & Ceratobasidium sp. & CNN \\
\hline $\mathrm{X} 2 \mathrm{SDS}$ & NA & 2013 & Illinois & Ceratobasidium sp. & CNN \\
\hline m_20_h & NA & 2012 & Whiteside Co., IL & Ceratobasidium sp. & $\mathrm{CNN}$ \\
\hline m_20_k & NA & 2012 & Whiteside Co., IL & Ceratobasidium sp. & CNN \\
\hline W_KSSO2_2_13 & NA & 2013 & Kansas & Ceratobasidium sp. & $\mathrm{CNN}$ \\
\hline 211 & NA & 2012 & Champaign Co., IL & R. zeae & M \\
\hline 12RS39 & NA & 2012 & DeKalb Co., IL & R. zeae & M \\
\hline $12 \mathrm{RS} 40$ & NA & 2012 & Jackson Co., IL & R. zeae & M \\
\hline 248_1a KH & NA & 2012 & Jackson Co., IL & R. zeae & M \\
\hline 248_2KH & NA & 2012 & Jackson Co., IL & R. zeae & M \\
\hline 12RS36 & NA & 2012 & McLean Co., IL & R. zeae & M \\
\hline 12RS48 & NA & 2012 & Peoria Co., IL & R. zeae & $\mathrm{M}$ \\
\hline
\end{tabular}


14 days, placed in $1.5-\mathrm{ml}$ microcentrifuge tubes, and stored at $-20^{\circ} \mathrm{C}$. DNA extraction was carried out using the FastDNA spin kit (MP Biomedicals, Santa Ana, CA) following the manufacturer's recommendations for fungal DNA isolation. Not all isolates identified as $R$. solani could be classified to AG using the traditional hyphal reaction technique; therefore, a polymerase chain reaction (PCR)restriction fragment length polymorphism (RFLP) analysis of the internal transcribed spacer (ITS) regions of the ribosomal DNA (rDNA) was initially conducted on all tester isolates and then on the recovered $R$. solani isolates to allow for a comparison of restriction patterns and final AG typing. For this analysis, genomic DNA was amplified using primer pairs RS1 (5'-CCTGTGCACCTGTGA GACAG-3') and RS4 (5'-TGTCCAAGTCAATGGACTAT-3') (Guillemaut et al. 2003). PCR assays were performed in a 40- $\mu 1$ mixture containing $20 \mu \mathrm{l}$ of GoTaq Green Master Mix 2X (Promega Corporation, Madison, WI), $4 \mu \mathrm{l}$ each of RS1 and RS4 primers, $4 \mu \mathrm{l}$ of nuclease-free water, and $8 \mu l$ of template DNA. PCR amplification was done in a 2720 thermal cycler (Applied Biosystems, Foster City, CA) using the following cycle parameters: initial denaturation at

Table 2. Tester isolates used for anastomosis group (AG) typing of unknown Rhizoctonia isolates recovered in this study

\begin{tabular}{llcl}
\hline & $\begin{array}{c}\text { Rhizoctonia } \\
\text { solani AG or } \\
\text { Thizoctonia } \text { spp. }\end{array}$ & $\begin{array}{c}\text { Accession } \\
\text { numbers }\end{array}$ & \multicolumn{1}{c}{ Source } \\
\hline Rh051307 & AG-2-1 & KX118375 & Tim Paulitz, WSU \\
Rh051324 & AG-2-1 & KX118376 & Tim Paulitz, WSU \\
Rh051339 & AG-4 HGII & KX118329 & Tim Paulitz, WSU \\
Rh0911029 & AG-5 & KX118377 & Tim Paulitz, WSU \\
R63_42A & R. zeae & KX118374 & Craig Rothrock, UA \\
HPIN22A & AG-11 & KX118355 & Craig Rothrock, UA \\
AG-9_Carling & AG-9 & KX118333 & Craig Rothrock, UA \\
AG-6_Carling & AG-6 & KX118332 & Craig Rothrock, UA \\
ST81548 & AG-7 & KX118384 & Craig Rothrock, UA \\
AG-4_Carling & AG-4 HGIII & KX118331 & Craig Rothrock, UA \\
USA_AG-3 & AG-3 & KX118385 & Berlin Nelson, NDSU \\
USA_AG-5 & AG-5 & KX118386 & Berlin Nelson, NDSU \\
AG2-2_Nelson & AG-2-2 & KX118328 & Berlin Nelson, NDSU \\
AG-4_Nelson & AG-4 HGII & KX118330 & Berlin Nelson, NDSU \\
65L-2 & AG-2-2IIIB & KX118334 & Sinclair, UIUC \\
\hline
\end{tabular}

${ }^{\mathrm{a}} \mathrm{WSU}=$ Washington State University, UA $=$ University of Arkansas, NDSU = North Dakota State University, and UIUC = University of Illinois at Urbana-Champaign.

b 65L-2 was originally collected by Liu and Sinclair (1991). $94^{\circ} \mathrm{C}$ for $3 \mathrm{~min}$; followed by 35 cycles of denaturation at $94^{\circ} \mathrm{C}$ for $30 \mathrm{~s}$, annealing at $55^{\circ} \mathrm{C}$ for $30 \mathrm{~s}$, and extension at $72^{\circ} \mathrm{C}$ for $1 \mathrm{~min}$; and a final extension at $72^{\circ} \mathrm{C}$ for $10 \mathrm{~min}$. Restriction analysis of PCR products was carried out in separate digestion reactions with the enzymes MseI (Fisher Scientific, Pittsburgh), MunI (Fisher Scientific), AvaII (Promega Corporation), and HincII (Promega Corporation) following the manufacturers' protocols. AvaII and HincII were combined in a single reaction for double digestion. Aliquots $(5 \mu \mathrm{l})$ of restriction fragments were checked on $2.5 \%$ agarose gel stained with GelRed Nucleic Acid Stain (Phenix Research, Candler, NC) and viewed with GelCam 310 Camera attached to a GelDoc-It2 Imager (UVP, LLC, Upland, CA). Restriction patterns of the unknown isolates and tester isolates were compared with those reported by Guillemaut et al. (2003) for correct placement of isolates into AG and subgroups.

The rDNA-ITS region of the AG-2-2IIIB isolates were amplified using AG-2-2IIIB-specific primers (Carling et al. 2002), while AG-3 isolates were amplified using both AG-3 (Lees et al. 2002) and AG-3 subgroup-specific primers (Kuninaga et al. 2000). Forward and reverse primers for the AG-2-2IIIB isolates were 5'-AGGCAGAG(A/G)CATG GATGGGAG-3'and $5^{\prime}$-ACCTTGGCCA(A/C)CCTTTTTATC-3'), respectively. For the AG-3 isolates, AG-3-specific primer pairs used were Rs1F2 (5'-TTGGTTGTAGCTGGTCTATTT-3') and Rs2R1 (5'-TAT CACGCTGAGTGGAACCA-3'), while the AG-3 subgroup-specific primer pair was 5'-GTTTGGTTGTAGCTGGCCC-3' and 5'-CTGA GATCCAGCTAATGT-3' for AG-3TB (tobacco type) and $5^{\prime}$ GTTTGGTTGTAGCTGGTCT- $3^{\prime}$ and 5'-CTGAGATCCAGCTAA TAC-3' for AG-3PT (potato type).

PCR amplification of rDNA-ITS regions, sequencing, and Bayesian inference of phylogeny. The rDNA-ITS regions of 57 collected (Table 1) and 15 tester (Table 2) isolates were amplified with the ITS-4 (5'-TCCTCCGCTTATTGATATGC- $\left.3^{\prime}\right)$ and ITS-5 (5'GGAAGTAAAAGTCGTAACAAGG-3') primers (White et al. 1990) in a final volume of $40 \mu \mathrm{l}$ using the PCR assays and cycle parameters described above. Successful amplification was confirmed by analyzing aliquots $(5 \mu \mathrm{l})$ of PCR products on $1 \%$ agarose gel and viewing with a GelCam 310 Camera attached to a GelDoc-It2 Imager (UVP, LLC). The PCR product for each isolate was purified with the Wizard SV Gel and PCR Clean-Up System (Promega Corporation) and sequenced at the McLab Molecular Cloning Laboratories (South San Francisco, CA) with the ITS-4 and ITS-5 primers. Using the software Sequencher 5.4 (Gene Codes Corporation, Ann Arbor, MI), the ITS sequences for both complimentary strands for each isolate were manually edited and assembled to produce a consensus sequence. Reference sequences representative of the AG of

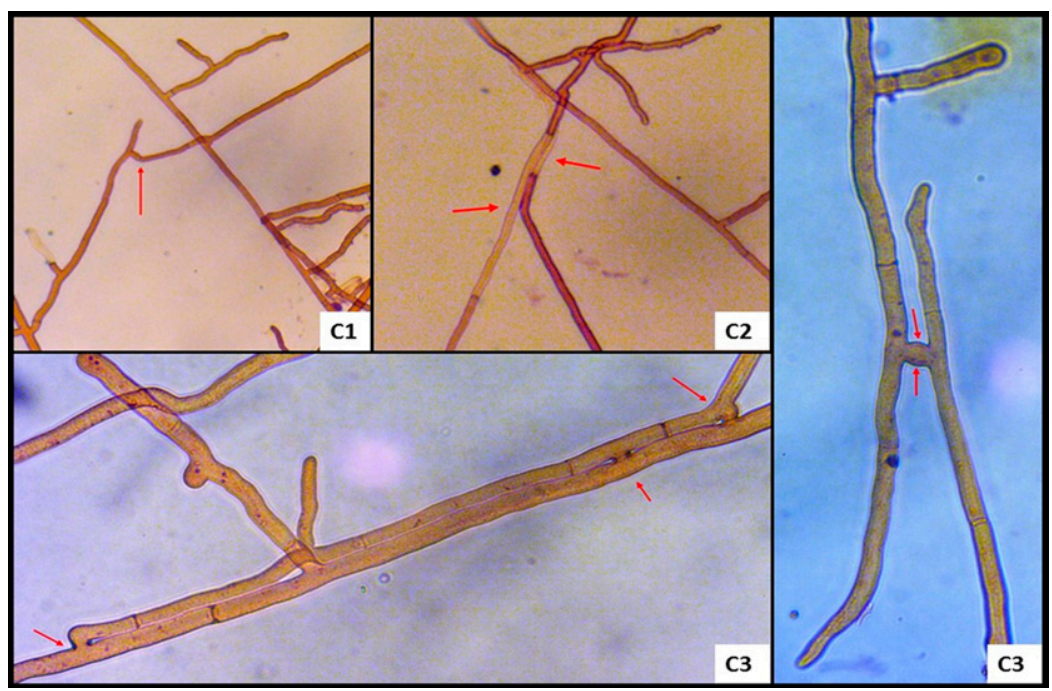

Fig. 1. Hyphal anastomosis reaction types for anastomosis group designation of Rhizoctonia solani isolates. $\mathrm{C} 1=$ cell wall contact only. $\mathrm{C} 2=$ cell wall fusion and death of anastomosing cells (killing reaction). C3 = perfect fusion of cell walls and cell membranes, and an absence of the killing reaction. 
$R$. solani as well as those of other species of Rhizoctonia were retrieved from the National Center for Biotechnology Information (NCBI) database (http://www.ncbi.nlm.nih.gov/) for identification of AG. To ascertain that all unknown isolates belonged to the genus Rhizoctonia, the consensus sequence of each isolate was queried using the BLASTN option (Altschul et al. 1997) in the NCBI database. Consensus sequence alignment for the unknown isolates $(n=57)$, tester isolates $(n=15)$, and those of the reference isolates $(n=24)$ was conducted using the ClustalW algorithm in the Molecular Evolutionary Genetics Analysis (MEGA version 6) Software (Tamura et al. 2013). Best-fit substitution model selection for phylogenetic analyses of the aligned consensus sequences was carried out using the Modeltest 3.7 program (Posada and Crandall 1998) implemented in PAUP* (Swofford 1998), with model selection strictly on the basis of the Akaike Information Criterion (AIC) estimate (Akaike 1974). Based on the AIC, the transversion model plus $\gamma(\mathrm{TVM}+\mathrm{G})$ was selected by Modeltest 3.7, with the following parameters: number of substitution types $=6$; rates at variable sites $=\gamma$; state frequencies for $\mathrm{A}, \mathrm{C}, \mathrm{G}$, and $\mathrm{T}=0.33,0.20,0.20$, and 0.27 , respectively; substitution rates for the TVM rate matrix AC, AG, AT, CG, CT, and GT= $0.75,2.71,1.07,0.68,2.71$, and 1.00 , respectively; shape parameter of the $\gamma$ distribution of rate variation $=0.37$; and proportion of invariable sites $=0$. A phylogenetic tree was then computed from the selected model and parameters using a Bayesian Metropolis-coupled Markov Chain Monte Carlo (MCMC) analysis implemented in MrBayes 3.2.6 (Ronquist and Huelsenbeck 2003). The MCMC analysis was run for 2 million generations with chain sampling every 500 generations. From the pool of trees constructed after convergence, $50 \%$ majority-rule trees were constructed. Bayesian posterior probability (PP) or clade support values were estimated from the consensus tree, and nodes with $\mathrm{PP} \geq 95 \%$ were considered strongly supported. Isolates were assigned to a species, AG, or subgroup if they clustered with a reference isolate in a strongly supported clade. Bayesian inference of phylogeny was repeated to replicate the results, and phylogenetic trees were visualized using the FigTree software (http://tree.bio. ed.ac.uk/software/figtree/).

Greenhouse pathogenicity assay. For greenhouse pathogenicity tests on soybean and corn, representative isolates from the Illinois collection were randomly selected. In all, 48 (Table 3) and 16 (Table 4) isolates representative of each of the identified AG and the other species of Rhizoctonia were evaluated in the greenhouse for their ability to cause hypocotyl and root rot symptoms on soybean and corn, respectively. Because isolates of AG-2-2IIIB were the most frequently recovered, the number of isolates within this group that was evaluated for pathogenicity was greater than that of other groups. This permitted an evaluation of the variability in aggressiveness of members of this group.

To prepare inoculum, the procedure described by Paulitz and Schroeder (2005) was adopted but with slight modifications. Briefly, sorghum seed were autoclaved for $30 \mathrm{~min}$ at $20 \mathrm{psi}$ and $120^{\circ} \mathrm{C}$. A second autoclaving was carried out after $24 \mathrm{~h}$ using the same parameters described for the first autoclaving. Plugs $(5 \mathrm{~mm})$ from 4-day-old cultures of each isolate were transferred to separate 250 -ml flasks containing autoclaved sorghum seed and incubated in the dark at $25^{\circ} \mathrm{C}$ for 2 weeks. Each flask was shaken at least twice per week to ensure uniform colonization of seed. After 2 weeks of incubation, seed were dried under a laminar flow hood for 3 days, packaged in paper bags, and stored at $4^{\circ} \mathrm{C}$ before use. A modified version of the inoculumlayer technique (Schmitthenner and Hilty 1962) was adopted for inoculation. Ten nontreated seeds of 'Williams 82' soybean were sown into 15 -cm-diameter plastic pots that had been previously half-filled with steam-pasteurized 2:1 sand-silt loam soil, covered with $5 \mathrm{~g}$ of inoculum, and covered with a 5-cm layer of soil. Control pots received noninfested autoclaved sorghum seed. The experiment was arranged as a completely randomized design with three replicates of each experimental unit (pots). The plants were grown in a greenhouse maintained at $24 \pm 3^{\circ} \mathrm{C}$ with a 14-h photoperiod and was repeated in a second trial. For corn, 20-cm-diameter pots were filled using the inoculum-layer technique described for soybean, and 10 seeds of nontreated 'Jubilee' sweet corn were sown directly over the uppermost soil layer. At 21 days after planting, plants were collected, roots were washed under a high-pressure flow nozzle, and plants were evaluated for disease severity on hypocotyls and roots. Roots were then dried for 4 days at $50^{\circ} \mathrm{C}$ and weighed. Disease severity was rated on a 0-to-5 scale modified from Nelson et al. (1996) as follows: $0=$ no lesion on root or hypocotyl; $1=$ lesions $<2.5 \mathrm{~mm}$ on hypocotyl and $\leq 20 \%$ of roots with lesions or rot symptoms; $2=$ lesions 2.5 to $5 \mathrm{~mm}$ on hypocotyl and 20 to $40 \%$ of roots with lesions

Table 3. Median disease rating (DR), mean rank, and estimated relative effect (RE) for the severity of hypocotyl and root rot symptoms caused by isolates of different Rhizoctonia spp. on soybean

\begin{tabular}{|c|c|c|c|c|c|c|}
\hline \multirow[b]{2}{*}{ Isolate } & \multirow{2}{*}{$\begin{array}{c}\text { Anastomosis } \\
\text { group }^{b}\end{array}$} & \multirow[b]{2}{*}{$\mathbf{D R}^{\mathrm{c}}$} & \multirow[b]{2}{*}{$\mathbf{R E}^{\mathbf{d}}$} & \multirow{2}{*}{$\begin{array}{c}\text { Mean } \\
\text { rank }\end{array}$} & \multicolumn{2}{|c|}{$\begin{array}{l}95 \% C I \\
\text { for } R^{a}\end{array}$} \\
\hline & & & & & $\mathbf{L L}$ & $\mathbf{U L}$ \\
\hline Control & $\ldots$ & 0 & 0.04 & 14.4 & 0.03 & 0.07 \\
\hline $\mathrm{X} 12 \mathrm{SDSa}$ & AG11 & 1 & 0.3 & 99 & 0.28 & 0.32 \\
\hline K_4_18b & AG11 & 1.75 & 0.45 & 148.5 & 0.33 & 0.58 \\
\hline S_P_19a & AG11 & 1 & 0.25 & 84.4 & 0.18 & 0.35 \\
\hline 211_1a & AG-2-2IIIB & 4 & 0.71 & 229.3 & 0.62 & 0.79 \\
\hline X42210_b & AG-2-2IIIB & 5 & 0.85 & 272 & 0.83 & 0.86 \\
\hline X42304_b & AG-2-2IIIB & 0.75 & 0.18 & 58.2 & 0.09 & 0.31 \\
\hline $65 \mathrm{~L}-2$ & AG-2-2IIIB & 5 & 0.85 & 272 & 0.83 & 0.86 \\
\hline DK_11 & AG-2-2IIIB & 5 & 0.85 & 272 & 0.83 & 0.86 \\
\hline DK_13 & AG-2-2IIIB & 4.5 & 0.75 & 241.3 & 0.65 & 0.82 \\
\hline DK_14 & AG-2-2IIIB & 5 & 0.85 & 272 & 0.83 & 0.86 \\
\hline DK_15a & AG-2-2IIIB & 4.75 & 0.72 & 233.6 & 0.60 & 0.82 \\
\hline DK_15b & AG-2-2IIIB & 5 & 0.85 & 272 & 0.83 & 0.86 \\
\hline DK_16 & AG-2-2IIIB & 5 & 0.82 & 262.6 & 0.75 & 0.87 \\
\hline DK_19 & AG-2-2IIIB & 3.25 & 0.61 & 199.3 & 0.47 & 0.74 \\
\hline DK_3a & AG-2-2IIIB & 5 & 0.82 & 263.9 & 0.76 & 0.87 \\
\hline DK_3b & AG-2-2IIIB & 2.5 & 0.54 & 178.4 & 0.44 & 0.65 \\
\hline DK_4a & AG-2-2IIIB & 4.5 & 0.75 & 242.5 & 0.66 & 0.82 \\
\hline DK_6b & AG-2-2IIIB & 5 & 0.85 & 272 & 0.83 & 0.86 \\
\hline DK_8 & AG-2-2IIIB & 5 & 0.82 & 262.6 & 0.75 & 0.87 \\
\hline ER_15 & AG-2-2IIIB & 5 & 0.85 & 272 & 0.83 & 0.86 \\
\hline ER_19a & AG-2-2IIIB & 4 & 0.67 & 216.1 & 0.48 & 0.81 \\
\hline ER_19b & AG-2-2IIIB & 5 & 0.82 & 263.9 & 0.76 & 0.87 \\
\hline ER_2 & AG-2-2IIIB & 5 & 0.85 & 272 & 0.83 & 0.86 \\
\hline ER_4 & AG-2-2IIIB & 5 & 0.79 & 253.2 & 0.70 & 0.85 \\
\hline K_IL_S02_3_25a & AG-2-2IIIB & 1 & 0.25 & 84.4 & 0.18 & 0.35 \\
\hline K_IL_S02_3_25c & AG-2-2IIIB & 5 & 0.82 & 263.9 & 0.76 & 0.87 \\
\hline X248_3bKH & AG-3 & 1 & 0.3 & 99 & 0.28 & 0.32 \\
\hline C_far_500_10a & AG-3 & 1 & 0.22 & 72.8 & 0.14 & 0.33 \\
\hline C_far_500_3 & AG-3 & 1 & 0.26 & 87.3 & 0.20 & 0.34 \\
\hline C_far_500_6 & AG-3 & 1 & 0.3 & 99 & 0.28 & 0.32 \\
\hline USA_AG-3 & AG-3 & 1 & 0.3 & 99 & 0.28 & 0.32 \\
\hline BVT_11 & AG-4 HGI & 1 & 0.34 & 112.7 & 0.27 & 0.43 \\
\hline EV_3 & AG-4 HGI & 1.75 & 0.49 & 162.5 & 0.42 & 0.57 \\
\hline EV_6 & AG-4 HGI & 1.5 & 0.49 & 158.4 & 0.32 & 0.66 \\
\hline BVT_28 & AG-4 HGIII & 1.25 & 0.37 & 121.1 & 0.25 & 0.51 \\
\hline BVT_3 & AG-4 HGIII & 1 & 0.34 & 112.7 & 0.27 & 0.43 \\
\hline BVT_16 & AG-7 & 2 & 0.52 & 170.6 & 0.43 & 0.60 \\
\hline BVT_20 & AG-7 & 1 & 0.38 & 126.3 & 0.29 & 0.49 \\
\hline EV_19 & AG-7 & 2 & 0.5 & 164.9 & 0.42 & 0.58 \\
\hline EV_7 & AG-7 & 1 & 0.34 & 112.7 & 0.27 & 0.43 \\
\hline K_2_1a & $\mathrm{BR}$ & 0.25 & 0.13 & 43.6 & 0.06 & 0.27 \\
\hline K_1_24c & $\mathrm{BR}$ & 1 & 0.25 & 84.4 & 0.18 & 0.35 \\
\hline m_24_c & BR & 1 & 0.26 & 87.3 & 0.20 & 0.34 \\
\hline SP_18_c & BR & 1 & 0.3 & 98.6 & 0.21 & 0.41 \\
\hline W_2_2_15 & $\mathrm{BR}$ & 0.5 & 0.17 & 55.3 & 0.08 & 0.31 \\
\hline $12 \mathrm{RS} 40$ & Rhizoctonia zeae & 0.5 & 0.14 & 46.5 & 0.07 & 0.27 \\
\hline 248_2KH & R. zeae & 1 & 0.22 & 72.8 & 0.14 & 0.33 \\
\hline W2_1__12 & R. zeae & 1 & 0.25 & 84.4 & 0.18 & 0.35 \\
\hline
\end{tabular}

${ }^{a}$ Confidence interval $(\mathrm{CI})$ for the $\mathrm{RE}\left(\hat{p}_{i j}\right)$ of each isolate was calculated using the LD_CI macro written by Brunner et al. (2002). LL and UL = lower and upper limit, respectively.

${ }^{\mathrm{b}} \mathrm{BR}=$ binucleate Rhizoctonia .

${ }^{\mathrm{c}}$ Median DR was on a scale of 0 to 5 .

${ }^{\mathrm{d}} \mathrm{RE}$ were determined as described by Shah and Madden (2004). 
or rot symptoms; $3=$ lesions $>5 \mathrm{~mm}$ on hypocotyl and 40 to $60 \%$ of roots with lesions or rot symptoms; 4 = lesions girdling entire hypocotyl and 60 to $80 \%$ of roots with lesions or rot symptoms; and $5=$ plant dead, or no roots, or $>80 \%$ of roots with lesions or rot symptoms. Statistical analyses were carried out in SAS (version 9.4; SAS institute Inc., Cary, NC). Disease severity data were subjected to nonparametric analysis using the rank-based method described by Shah and Madden (2004). Briefly, median ratings of the 10 plants constituting an experimental unit were obtained before further analysis. Ordinal ratings were converted to midranks using PROC RANK, and midranks obtained were then used by PROC MIXED to calculate significance levels and nonparametric test statistics. Relative treatment effect $\left(\hat{p}_{i j}\right)$ of each individual isolate and confidence intervals (CI) of relative treatment effects were obtained using the LD_CI macro written by Brunner et al. (2002) and available at http://www.ams.med.uni-goettingen.de/sasmakr-de.shtml.

\section{Results}

Morphological characterization. Of the 114 isolates recovered from Illinois, Arkansas, Kansas, Michigan, Minnesota, and Ontario, 80 were identified as $R$. solani, 10 as $R$. zeae, and 24 as BR (Ceratobasidium spp.). The $80 R$. solani isolates were characterized as belonging to five AG as follows: AG-2 (with two subgroups; AG-2-1 $[n=1]$ and AG-2-2IIIB $[n=52])$, AG-3 $(n=5)$, AG-4 $(n=5)$, AG-7 $(n=9)$, and AG-11 $(n=8)$. All $R$. solani isolates exhibited macroscopic and microscopic characteristics typical of members of the species (Figs. 2A-D and 3). On PDA, young vegetative hyphae were hyaline when young but became brown with age, and hyphal cells were multinucleate. Cellular nuclear number of young vegetative hyphae ranged from 4 to 12 nuclei, with considerable variation among AG (Table 5). After 2 weeks of incubation, the AG-2-1 isolate produced thick-walled, brown sclerotia that darkened with prolonged incubation. The AG-2-1 isolate produced a $\mathrm{C} 2$ reaction with the AG-2-1 tester isolate Rh051307 (KX118375), indicating genetic distinctiveness. Isolates of AG-2-2IIIB exhibited marked similarity in cultural appearance; colonies appeared brown with age with zonation, and the thick-walled, brown sclerotia produced darkened with prolonged incubation. All AG-2-2IIIB isolates grew at $35^{\circ} \mathrm{C}$, and the $10 \mathrm{AG}-2-2 \mathrm{IIIB}$ selected for anastomosis reaction assays produced

Table 4. Median disease rating (DR), mean rank, and estimated relative effect (RE) for the severity of hypocotyl and root rot symptoms caused by isolates of different Rhizoctonia spp. on corn

\begin{tabular}{|c|c|c|c|c|c|c|}
\hline \multirow[b]{2}{*}{ Isolate } & \multirow[b]{2}{*}{ Anastomosis group ${ }^{\mathbf{b}}$} & \multirow[b]{2}{*}{$\mathbf{D R}^{\mathbf{c}}$} & \multirow[b]{2}{*}{$\mathbf{R E}^{\mathbf{d}}$} & \multirow[b]{2}{*}{ Mean rank } & \multicolumn{2}{|c|}{$\begin{array}{l}95 \% C I \\
\text { for } R^{a}\end{array}$} \\
\hline & & & & & $\mathbf{L L}$ & UL \\
\hline Control & Control & 0 & 0.25 & 26.0 & 0.18 & 0.34 \\
\hline X12SDSa & AG-11 & 2 & 0.68 & 69.5 & 0.64 & 0.71 \\
\hline K_4_18b & AG-11 & 1 & 0.50 & 51.6 & 0.39 & 0.61 \\
\hline S_P_19a & AG-11 & 2.5 & 0.73 & 75.2 & 0.66 & 0.79 \\
\hline $65 \mathrm{~L}-2$ & AG-2-2IIIB & 4.5 & 0.92 & 94.3 & 0.89 & 0.94 \\
\hline DK_3a & AG-2-2IIIB & 3.5 & 0.82 & 84.0 & 0.79 & 0.85 \\
\hline ER_2 & AG-2-2IIIB & 3 & 0.81 & 82.8 & 0.77 & 0.84 \\
\hline C_far_500_6 & AG-3 & 0 & 0.25 & 26.0 & 0.18 & 0.34 \\
\hline USA_AG3 & AG-3 & 0.25 & 0.38 & 39.2 & 0.25 & 0.53 \\
\hline X248_3bKH & AG-3 & 0 & 0.25 & 26.0 & 0.18 & 0.34 \\
\hline EV_6 & AG-4 HGI & 5 & 0.96 & 98.0 & 0.94 & 0.96 \\
\hline BVT_20 & AG-7 & 1 & 0.54 & 55.3 & 0.41 & 0.66 \\
\hline EV_19 & AG-7 & 0 & 0.25 & 26.0 & 0.18 & 0.34 \\
\hline $\mathrm{K} \_2 \_1 \mathrm{a}$ & BR & 0 & 0.27 & 28.3 & 0.18 & 0.40 \\
\hline W_2_2_15 & BR & 0 & 0.26 & 26.7 & 0.18 & 0.35 \\
\hline $12 \mathrm{RS} 40$ & Rhizoctonia zeae & 0 & 0.25 & 26.0 & 0.18 & 0.34 \\
\hline 248_2KH & R. zeae & 0.5 & 0.39 & 40.8 & 0.26 & 0.55 \\
\hline
\end{tabular}

${ }^{a}$ Confidence interval $(\mathrm{CI})$ for the $\mathrm{RE}\left(\hat{p}_{i j}\right)$ of each isolate was calculated using the LD_CI macro written by Brunner et al. (2002). LL and UL = lower and upper limit, respectively.

${ }^{\mathrm{b}} \mathrm{BR}=$ binucleate Rhizoctonia .

${ }^{\mathrm{c}}$ Median DR was on a scale of 0 to 5 .

${ }^{\mathrm{d}} \mathrm{RE}$ were determined as described by Shah and Madden (2004). a C2 reaction with the AG-2-2IIIB tester isolate 65L-2 (KX118334). Cultures of AG-3 isolates were buff in color, with no zonation or apparent pigmentation. Also, sclerotia, which were seldom produced, appeared embedded in PDA around the edges of the plate. Anastomosis reactions between the recovered AG-3 isolates and the AG-3 tester isolate, USA_AG-3 (KX118385), produced a C2 reaction type. The five AG-4 isolates produced brown colonies on PDA with no zonation or apparent pigmentation. Occasionally, a few olive-brown sclerotia developed around the inoculation point on PDA. There were no differences in growth among the four isolates at $25^{\circ} \mathrm{C}$, and all four isolates produced a $\mathrm{C} 3$ reaction type when anastomosed with AG-4 tester isolate Rh051339 (KX118329). Traditional anastomosis analysis using AG-4 subgroup-specific tester isolates did not permit classification of the AG-4 isolates into subgroups. The AG-7 isolates exhibited similarity in cultural morphology to the AG-4 isolates; the colony appeared brown at 2 weeks after incubation, with clusters of sclerotia occurring mostly at the point of inoculation in PDA. However, none of the AG-7 isolates anastomosed with any of the AG-4 or AG-7 tester isolates. The AG-11 isolates produced lightbrown mycelia on PDA at 5 days after incubation at $25^{\circ} \mathrm{C}$ but colony color became dark-brown with age. Two of the AG-11 isolates produced yellow pigmentation on PDA. Abundant sclerotia, ranging from light tan to brown, were densely distributed on the surface of the PDA. All AG-11 isolates produced a $\mathrm{C} 2$ reaction type when anastomosed with AG-11 tester isolate HPIN22A (KX118355). For all $\mathrm{BR}$, two nuclei per cell were observed in young vegetative hyphae (Fig. 2E), and no sclerotia were observed in culture after 2 weeks of incubation. Isolates identified as $R$. zeae had multinucleate cell compartments with 4 to 7 nuclei and produced salmon-orange colonies on PDA. In addition, white spherical sclerotia formed, which turned orange to red with age and appeared submerged in PDA.

Rhizoctonia spp. by location. Of the total number of isolates characterized in this study, 77 were recovered from Illinois, 10 from Arkansas, 1 from Kansas, 1 from Michigan, 1 from Minnesota, and 24 from Ontario, Canada (Fig. 4). The identity of the Illinois isolates are as follows: AG-2-2IIIB $(n=28)$, AG-3PT $(n=5)$, AG-4 HGI $(n=3)$, AG-4 HGIII $(n=2)$, AG-7 $(n=4)$, AG-11 $(n=6)$, Ceratobasidium spp. $(n=19)$, and $R$. zeae $(n=10)$. Five of the Arkansas isolates were AG-7, two were AG-11, one was AG-2-1, and two were Ceratobasidium spp. The Kansas, Michigan, and Minnesota isolates were Ceratobasidium spp., whereas all 24 isolates from Ontario were AG-2-2-IIIB.

PCR-RFLP analysis of the rDNA-ITS regions and PCR analysis with AG-specific primers for AG typing of $R$. solani isolates. Restriction patterns obtained from the digestion of $71 R$. solani isolates with the restriction enzymes MseI, MunI, AvaII, and HincII corresponded well with those obtained by Guillemaut et al. (2003). Of the different RFLP types they reported for AG-2-1, only "DANN" was observed for both the AG-2-1 isolate from Arkansas and the AG-2-1 tester isolates Rh051307 (KX118375) and Rh051324 (KX118376). All of the AG-2-2IIIB isolates characterized by restriction analysis produced a "CAAN" RFLP type. None of the four AG-3 isolates could be typed to either AG or subgroup by restriction analysis. Restriction analysis permitted the classification of all AG-4 isolates into subgroups, producing "IEAA", and "LENA" RFLP types for the AG-4 HGI and AG-4 HGIII isolates, respectively. Two RFLP types were observed for the AG-7 isolates; AG-7 tester isolate ST81548 (KX118384) produced "DNNN", while the AG-7 isolates recovered from Arkansas produced an "ENNA". The AG-7 isolates from Illinois could not be resolved by restriction analysis. All AG-11 isolates produced a "BNAA" RFLP type. All isolates identified as AG-2-2IIIB were successfully amplified with the AG-2-2IIIBspecific primers, producing a single amplicon of approximately $0.50 \mathrm{~kb}$. The AG-3PT primer pair gave a single product of approximately $0.5 \mathrm{~kb}$ for the five AG-3 isolates recovered from Illinois, while the AG-3TB primer produced a single amplicon of about $0.5 \mathrm{~kb}$ for the AG-3 tester isolate USA_AG3.

Phylogenetic analysis of rDNA-ITS region. Phylogenetic analysis of the rDNA-ITS sequence data permitted the classification of the recovered isolates into well-established AG or subgroups of different 
Rhizoctonia spp. Of the 57 isolates analyzed for phylogenetic relationship with reference isolates from the GenBank and tester isolates, 56 were identified based on the PP obtained from the Bayesian analysis (Fig. 5). Three isolates clustered and formed a strongly supported clade $(\mathrm{PP}=100 \%)$ with tester isolate R63_42A (KX118374) and with an $R$. zeae accession from Japan (AB213594). Sixteen isolates were identified as Ceratobasidium spp. and were located in two distinct clades. In the first clade, which consisted mainly of BR isolates, 1 isolate clustered with the Ceratobasidium sp. AG-L reference isolates from Japan (AB286933; PP $=100 \%$ ), while 12 isolates clustered with a Ceratobasidium sp. AG-A reference isolate from Japan (AF354092; $\mathrm{PP}=100 \%$ ). The remaining three Ceratobasidium spp. were found to group in a clade consisting of $R$. solani isolates. Although two of these isolates grouped closely with two Ceratobasidium sp. AG-F reference isolates $(\mathrm{PP}=100 \%)$ in a clade comprising AG-4 and AG-7 isolates, one clustered with an AG-6 tester isolate (KX118332) and an AG-6 reference isolate from Japan (AF354102). Within the $R$. solani clade, two $R$. solani AG-7 clades were observed. The first clade $(\mathrm{PP}=$ $100 \%$ ) comprised the AG-7 tester isolate ST81548 (KX118384) and a reference AG-7 isolate AF354098 from Japan, while the second clade ( $\mathrm{PP}=100 \%)$ included nine recovered isolates: four from Illinois, four from Arkansas, and an $R$. solani AG-7 reference isolate from Arkansas (AF153793). Two isolates grouped with $R$. solani AG-4 HGI reference isolate $\mathrm{AB} 000007$ from Japan $(\mathrm{PP}=100 \%)$ and two others clustered with AG-4 tester isolate KX118331 and $R$. solani AG-4 HGIII reference isolate AY154659 from Brazil (PP = 100\%). One recovered isolate (KX118363) clustered with an $R$. solani AG2-1 reference isolate AY154317 from Brazil with a PP of 98\%. Thirteen recovered isolates and two tester isolates, 65L-2 (KX118334) and AG-2-2_Nelson (KX118328), clustered together and formed strongly supported clades with two $R$. solani AG-2-2IIIB reference isolates, AF354116 and GU811670, from Japan and the United States, respectively. Seven isolates were identified as $R$. solani AG-11 based on a PP value of $100 \%$ from a clade formed with tester isolate HPIN22A

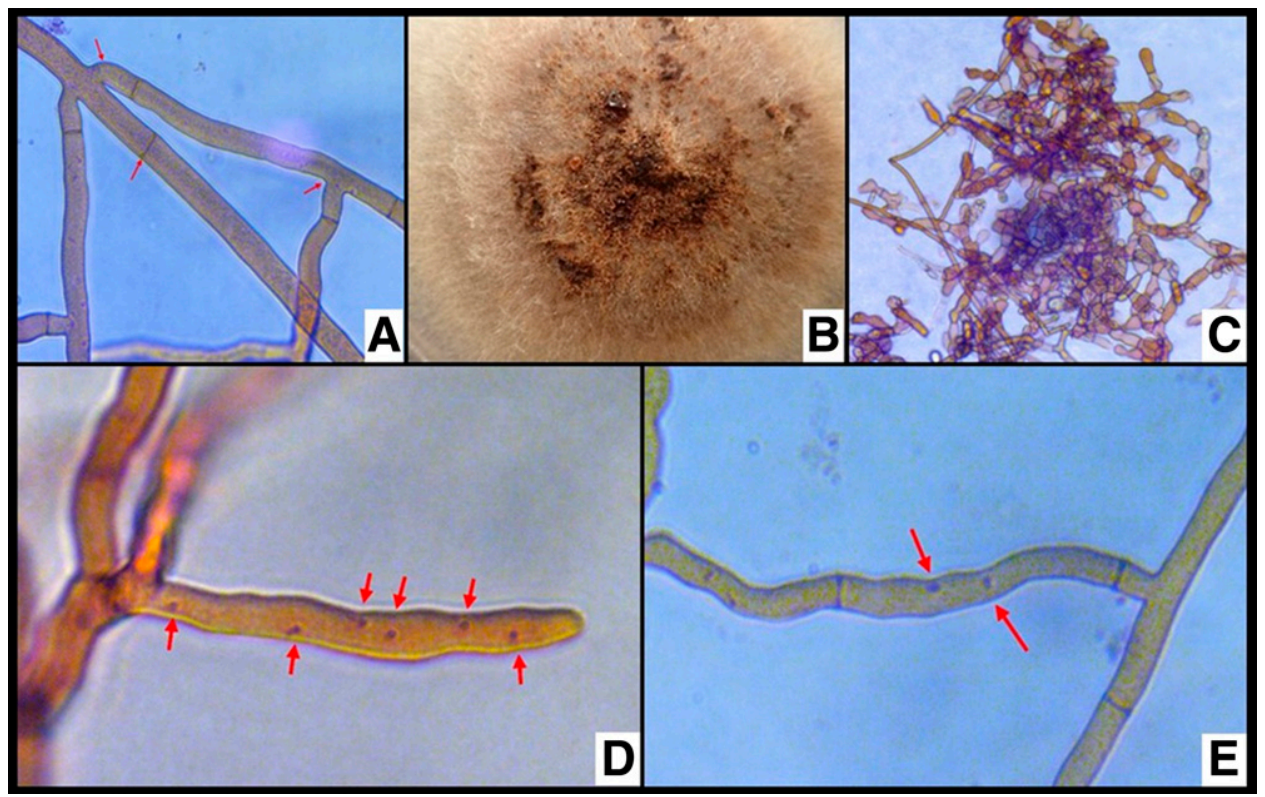

Fig. 2. Microscopic and macroscopic characteristics of Rhizoctonia solani. A, Right-angled branching of septate hyphae. B, Dark-brown sclerotia of a growing colony on potato dextrose agar. C, Monilioid cells of sclerotia. D, Multinucleate Rhizoctonia. E, Binucleate Rhizoctonia.

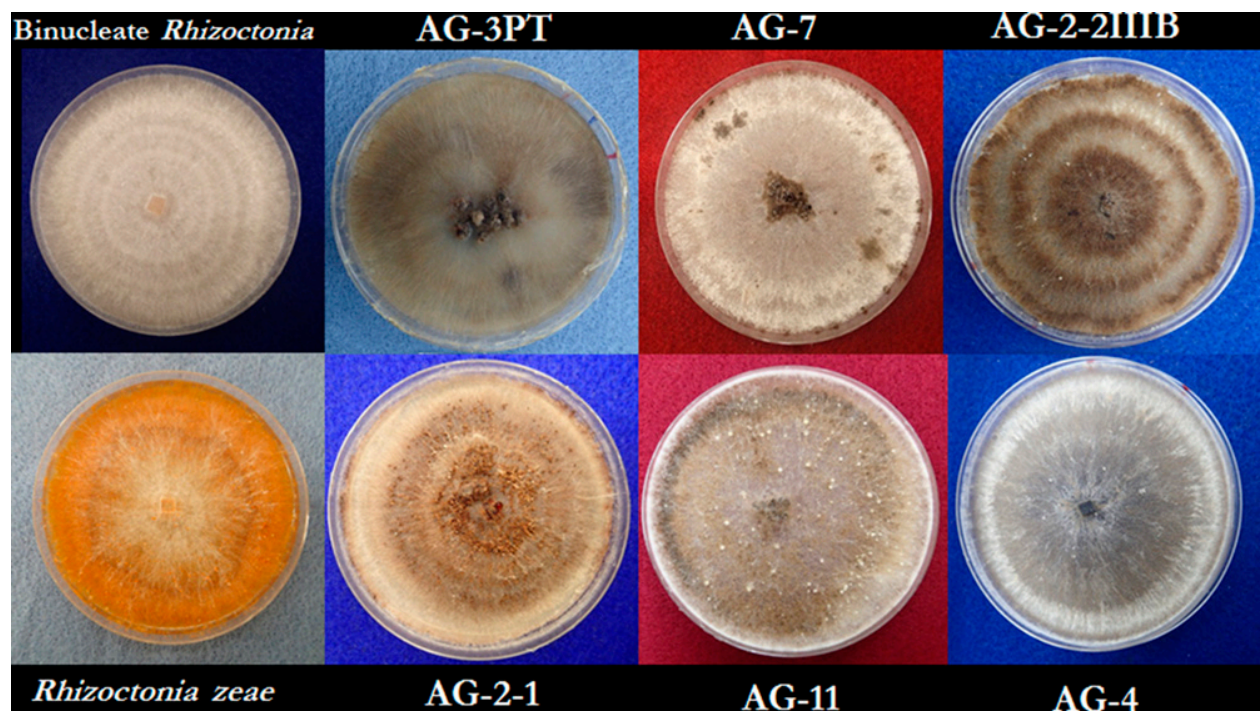

Fig. 3. Colony morphology of the binucleate Rhizoctonia, Rhizoctonia zeae, and some select anastomosis groups (AG) of Rhizoctonia solani. 
(KX118355) and an AG-11 reference isolate AF354114 from the United States. Five isolates formed a strongly supported clade $(\mathrm{PP}=100 \%)$ with USA_AG-3 tester isolate (KX118385) and an AG-3 reference isolate (GQ885147) from the United States.

Pathogenicity on soybean. Forty-eight isolates were evaluated for their ability to incite disease on the roots and hypocotyls of soybean in the greenhouse. Of these, 23 were AG-2-2IIIB, 5 were AG-3, 5 were AG-4, 4 were AG-7, 3 were AG-11, 5 were BR, and 3 were $R$. zeae. Based on median disease ratings, estimated relative effect $\left(\hat{p}_{i j}\right)$, and mean ranks, isolates of AG-2-2IIIB were the most aggressive on the roots and hypocotyls of soybean, followed by those of AG-7, AG-4, AG-11, AG-3, BR, and $R$. zeae (Table 3). The median disease severity ratings of the 48 isolates evaluated ranged from 0.25 to 5 , with relative treatment effects of 0.13 to 0.85 . Isolates of AG-22IIIB had the greatest median disease severity rating (ranging from 2.5 to 5 ), $\hat{p}_{i j}$ (ranging from 0.50 to 0.85 ), and mean ranks (ranging from 178.4 to 272 ), with the exception of two isolates that had median disease severity ratings of 0.75 and 1 and significantly lower $\hat{p}_{i j}(0.18$ and 0.25 , respectively) and mean ranks (58.2 and 84.4, respectively). Isolates of other AG of $R$. solani, BR, and $R$. zeae gave median disease ratings less than 2.0 and $\hat{p}_{i j}$ less than 0.50 .

Table 5. Variation in cellular nuclear number among anastomosis groups (AG) of Rhizoctonia solani identified in this study

\begin{tabular}{llr}
\hline & \multicolumn{2}{c}{ Cellular nuclear number } \\
\cline { 2 - 3 } Group & Range & Mode \\
\hline AG-2-2IIIB & 4 to 12 & 8 \\
AG-3 & 5 to 10 & 7 \\
AG-4 & 4 to 6 & 5 \\
AG-7 & 4 to 6 & 10 \\
AG-11 & 5 to 10 & 8 \\
Binucleate Rhizoctonia & 2 & 2 \\
R. zeae & 4 to 7 & 5 \\
\hline
\end{tabular}

Pathogenicity on corn. Three isolates each of AG-2-2IIIB, AG-3 and AG-11; two isolates each of AG-7, BR, and R. zeae; and one isolate of AG-4 were evaluated for their ability to incite disease on roots of corn. The median disease ratings ranged from 0 to 5 , with $\hat{p}_{i j}$ of 0.25 to 0.92 and mean ranks of 24.5 to 94.3 (Table 4). AG-2-2IIIB isolates produced the greatest median disease severity ratings (ranging from 2.5 to 4.5 ) while isolates of $\mathrm{BR}$ gave 0 as the median disease severity rating. Based on $\hat{p}_{i j}$ and their $95 \% \mathrm{CI}, \mathrm{AG}-2-2 \mathrm{IIIB}$ isolates were the most aggressive, although the single AG-4 isolate tested expressed similar levels of aggressiveness. Isolates of AG-3, AG-7, $\mathrm{BR}$, and $R$. zeae were not significantly different from the noninoculated control.

\section{Discussion}

In this study, isolates of Rhizoctonia recovered from symptomatic soybean plants between 2012 and 2014 from five states in the United States and from the Canadian province of Ontario were characterized and identified to AG, subgroups, and species. The pathogenicity of isolates representative of the identified groups was also determined to provide information on which of the groups present the greatest risk to soybean health in any soybean production field. Three taxonomic groups-R. solani (70\%), R. zeae (9\%), and Ceratobasidium spp. (21\%) — were identified. Isolates of $R$. solani were further identified to AG and subgroups as follows: AG-2-1, AG-2-2IIIB, AG3PT, AG-4 HGI, AG-4 HGIII, AG-7, and AG-11. Of the identified AG and Rhizoctonia spp., $R$. solani AG-2-2IIIB posed the greatest risk to soybean health at the seedling stage.

The diversity of $R$. solani AG recovered in this study is consistent with reports from other authors (Carling et al. 1994; Liu and Sinclair 1991; Muyolo et al. 1993a; Nelson et al. 1996; Rizvi and Yang 1996; Zhao et al. 2005). Combining all locations in which $R$. solani was recovered, isolates of AG-2-2IIIB represented the most frequently isolated population while AG-2-1 represented the least recovered group; however, considering each location, the number and diversity of AG recovered varied. Muyolo et al. (1993a) identified AG-2-2IIIB as the

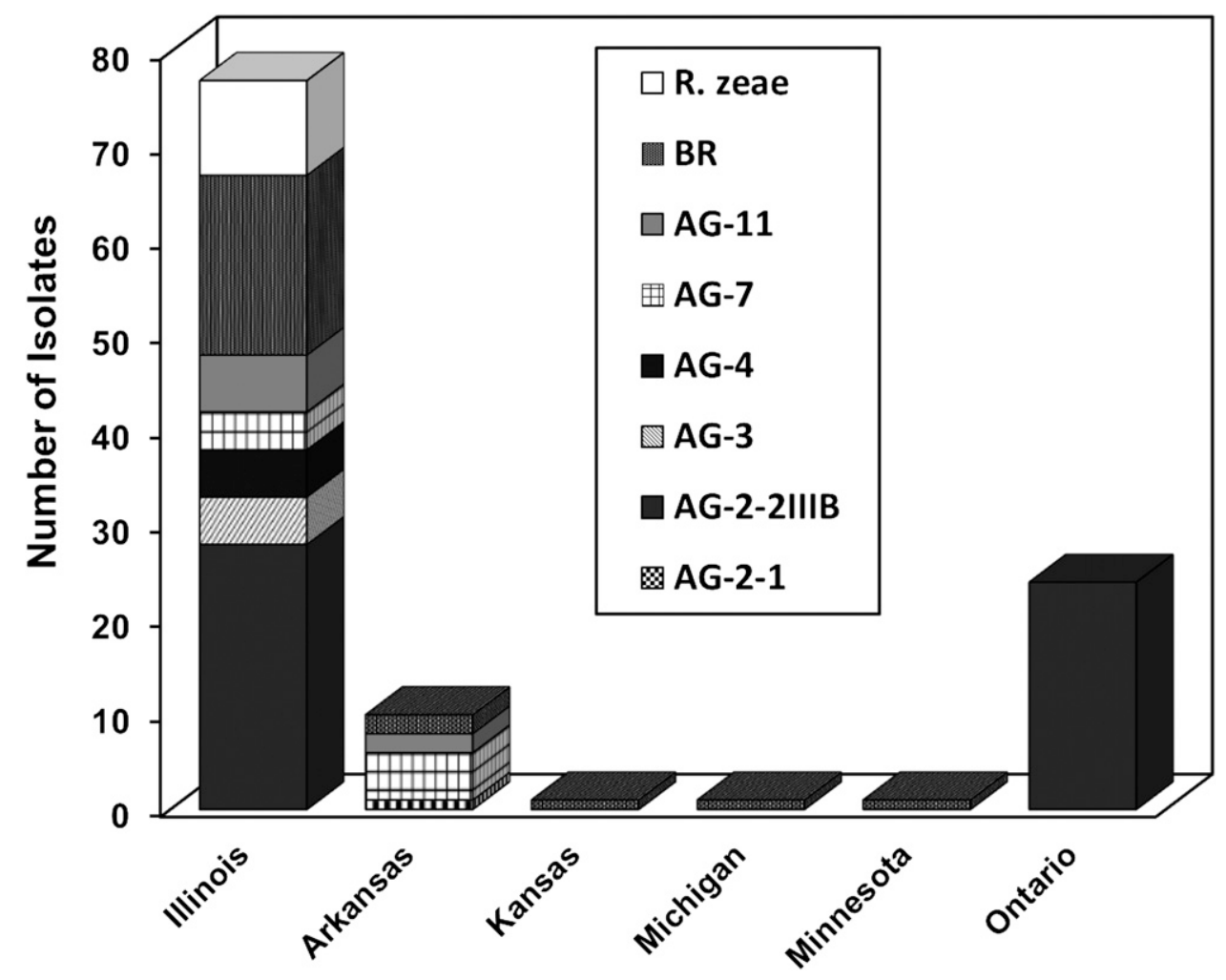

Fig. 4. Distribution by location of isolates of Rhizoctonia collected from soybean in Arkansas, Illinois, Kansas, Michigan, Minnesota, and the Canadian province of Ontario. BR = binucleate Rhizoctonia and $\mathrm{AG}=$ anastomosis group. 
predominant AG of $R$. solani in Ohio, and this was confirmed by Dorrance et al. (2003) a decade later. In Ontario, Canada, $86 \%$ of the $278 \mathrm{R}$. solani isolates recovered from diseased soybean plants were characterized as members of AG-2-2IIIB, while 1.4 and $12.6 \%$ belonged to AG-4 and AG-5, respectively (Zhao et al. 2005). However, these observations are in contrast to observations from other U.S. soybean-growing regions. In the Red River Valley of North Dakota and Minnesota, isolates of $R$. solani AG-2, AG-3,
AG-4, and AG-5, in addition to other species of Rhizoctonia, were recovered from diseased soybean plants obtained from 200 fields, with AG-4 isolates being recovered more frequently (Nelson et al. 1996). Similarly, in Iowa, AG-4 was the predominant group isolated from diseased soybean seedlings (Rizvi and Yang 1996). In our study, no AG-5 isolate was recovered and very few AG-4 isolates were recovered from Illinois. The reasons for the disparity in the predominant AG across different soybean-growing regions is uncertain

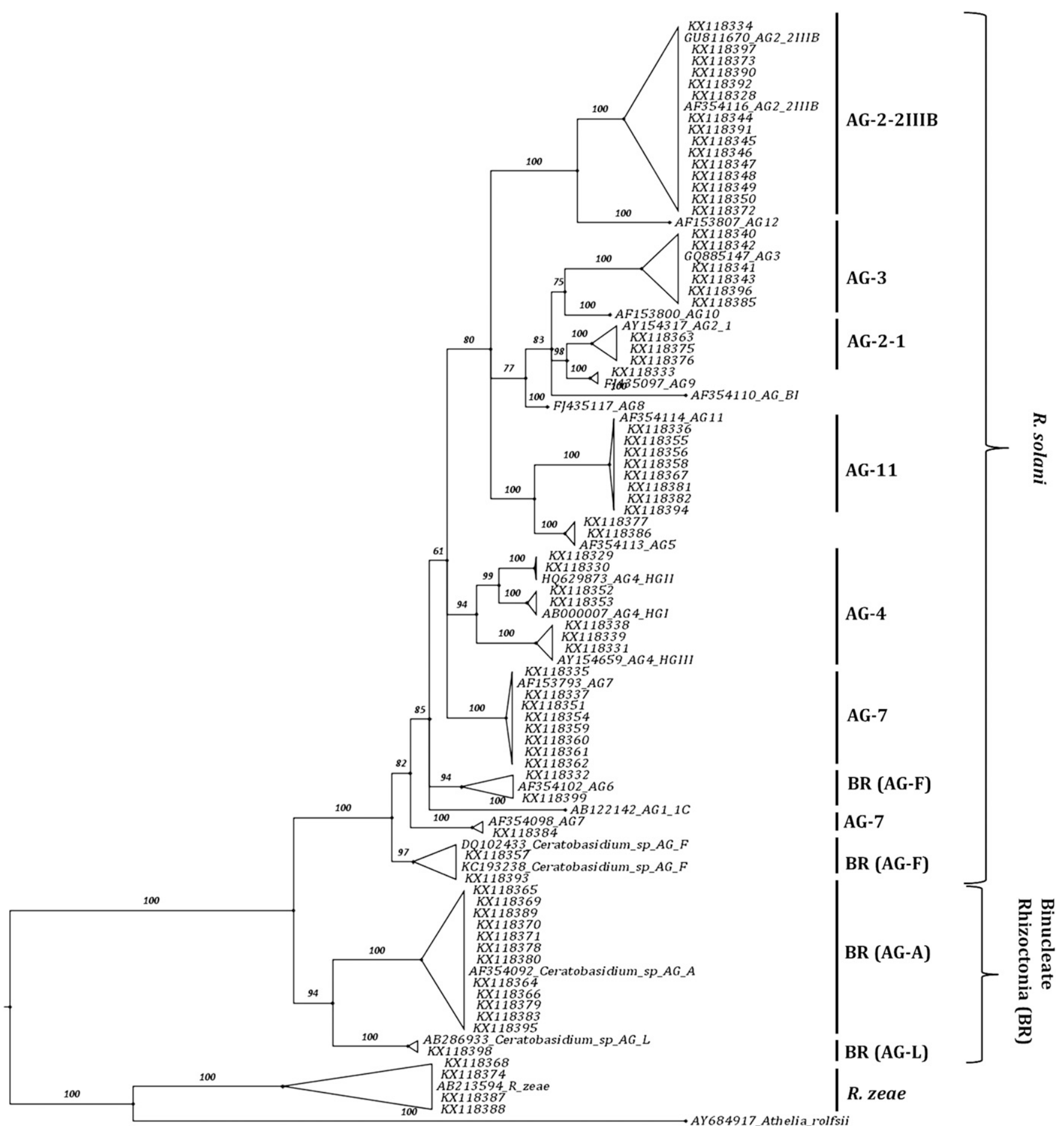

004

Fig. 5. Consensus tree generated from the Bayesian analysis of the ribosomal DNA internal transcribed spacer (ITS)1-5.8S-ITS2 region of selected Rhizoctonia isolates from Arkansas, Illinois, Michigan, Minnesota, and the Canadian province of Ontario. Reference isolates from the National Center for Biotechnology Information database are indicated with accession numbers, followed by anastomosis group (AG)/subgroup/species designation. BR = binucleate Rhizoctonia. Numbers above branches represent Bayesian posterior probability values in percentage. 
but may be attributed to differences in cropping systems (Ogoshi 1987) or soil type associated with the different states. The diversity of AG recovered from Arkansas is consistent with previous reports. In the United States, isolates of AG-7 (Rothrock et al. 1993) and AG11 (Carling et al. 1994) were first reported on soybean seedlings in Arkansas. Also, AG-11 isolates have been associated with fields under repeated rice-soybean rotations in Arkansas (Spurlock et al. 2016) and Texas (Jones and Carling 1999). However, this is the first report of AG-2-1 in this region and the first time AG-2-1 was isolated from soybean seedlings. AG-2-1 is known to be pathogenic on a number of host crops (Sneh et al. 1991), including pea (Hwang et al. 2007; Sharma-Poudyal et al. 2015), canola (Paulitz et al. 2006), tulip (Nakatomi and Kaneko 1971), and crucifers (Ogoshi 1987; Watanabe and Matsuda 1966), and no researchers have reported this AG as a major pathogen of soybean or corn. The role of this AG in the ecology of $R$. solani on soybean deserves further investigation. The diversity of AG observed in Illinois is unexpected given the less diverse cropping pattern typical of this region. With the corn-soybean rotation being the primary rotation regime in Illinois, the detection of AG known to be pathogenic on other crops not cultivated in this region is rather surprising. Isolates of AG-3 are well established pathogens of members of the Solanaceae family (Anderson 1982; Kuninaga et al. 2000; Meyer et al. 1990; Ogoshi 1987), AG-7 are pathogens of cotton and watermelon (Baird and Carling 1995, 1997; Baird et al. 1996), and AG-11 are pathogens of lupine, cotton, and radish (Carling et al. 1994; Sweetingham 1989). The identification of these AG on diseased soybean seedlings may imply an expansion of host range to include soybean. The recovery of only AG-2-2IIIB isolates from Ontario suggests that there has not been a change in the $\mathrm{AG}$ of $R$. solani causing seedling diseases of soybean in that region.

The single isolate recovered from Kansas, Minnesota, and Michigan was identified as a Ceratobasidium sp. Ceratobasidium spp. are Rhizoctonia-like fungi with binucleate cells (Sneh et al. 1991) and, similar to $R$. solani, members of the genus Ceratobasidium have been classified into seven Ceratobasidium AG (CAG-1 to CAG-7) (Burpee et al. 1980a), although these were later expanded to 17 AG (AG-A to AG-Q) (Ogoshi et al. 1983). The low frequency of $R$. solani recovery from these states was rather surprising. At least four AG of $R$. solani have been associated with soybean seedlings in Minnesota (Nelson et al. 1996) and, in Michigan, R. solani AG-2, AG-3, and AG-4 are widespread (Wharton et al. 2006). Therefore, the reason for their low recovery rate in this study was probably due to sampling or isolation protocols. The isolation of $R$. zeae from soybean seedlings was infrequent. Moreover, all $R$. zeae isolates identified in this study were recovered from Illinois, and this is the first report of this Rhizoctonia sp. on soybean seedlings in this region. $R$. zeae are multinucleate Rhizoctonia that are differentiated from $R$. solani by their distinctive salmon-colored mycelia in culture (Burpee and Martin 1992). They are major pathogens of corn and turfgrass species (Burpee and Martin 1992; Martin and Lucas 1984a; Sumner and Bell
1982; Voorhees 1934), and their frequent isolation from organic debris and soils associated with symptomatic host plants (Martin and Lucas 1984a) suggests an excellent saprophytic potential. Given that corn is a major rotational crop in Illinois, $R$. zeae recovered on symptomatic soybean seedlings might have originated from the inoculum on corn residue.

Molecular characterization using the ITS sequence of the ribosomal genes has been identified as the most reliable approach for the phylogenetic studies of AG and subgroups of different Rhizoctonia spp. (Gonzalez et al. 2001; Sharon et al. 2006). Using the ITS sequence data of the recovered isolates and those from the NCBI database, we were able to corroborate the results obtained using other characterization techniques and make inferences regarding the phylogenetic relationships among the isolates. Phylogenetic analysis also allowed for the identification of certain $R$. solani isolates that remained unidentified using other AG-typing techniques. For example, the four AG-7 isolates from Illinois grouped strongly with AG-7 isolates collected from Arkansas and the AG-7 reference isolate, which also was recovered from Arkansas (AF153793). A second AG-7 clade comprised an AG-7 tester isolate, ST81548, and an AG-7 reference isolate from Japan (AF354098) also was observed. The origin of ST81548 is unknown but it does appear that the two AG-7 clusters observed in this study correspond to different AG-7 subgroups. Additional work involving representative isolates from different hosts and origins needs to be done to test this hypothesis. For the first time in the United States, AG-4 HGI was identified on soybean. In the United States, AG-4 isolates from soybean have been characterized as HGII and HGIII, while those associated with hypocotyl rot in Brazil have been identified as HGI. Phylogenetic analysis also revealed different clades that corresponded to well-established AG of different Rhizoctonia spp. Based on PP values, there was strong support ( $>95 \%$ ) for AG-2-1, AG-2-2IIIB, AG-3, AG-4, AG7, and AG-11 clusters. The AG-2-1 and AG-2-2IIIB isolates did not cluster together on the phylogenetic tree despite being members of the same AG. This observation is not surprising given that polyphyly among members of this AG has been reported by several authors (Budge et al. 2009; González et al. 2006; Kuninaga et al. 1997; Ohkura et al. 2009; Salazar et al. 1999, 2000; Sharon et al. 2008; Stodart et al. 2007).

Despite the strong support (100\%) for the separation of the Ceratobasidium spp. and the $R$. solani isolates, certain Ceratobasidium isolates clustered with isolates of $R$. solani. This suggests that certain Ceratobasidium spp. are more closely related to some $R$. solani isolates than they are to other members of genus Ceratobasidium. Similar observations indicating genetic relatedness between Ceratobasidium spp. and some $R$. solani isolates have been reported by several authors. For example, Gonzalez et al. (2001) found that certain BR belonging to CAG-4 and CAG-6 clustered closely with $R$. solani AG-4 isolates. Similarly, cluster analysis of rDNA-ITS region sequences of Rhizoctonia isolates recovered from strawberry in Israel grouped Ceratobasidium
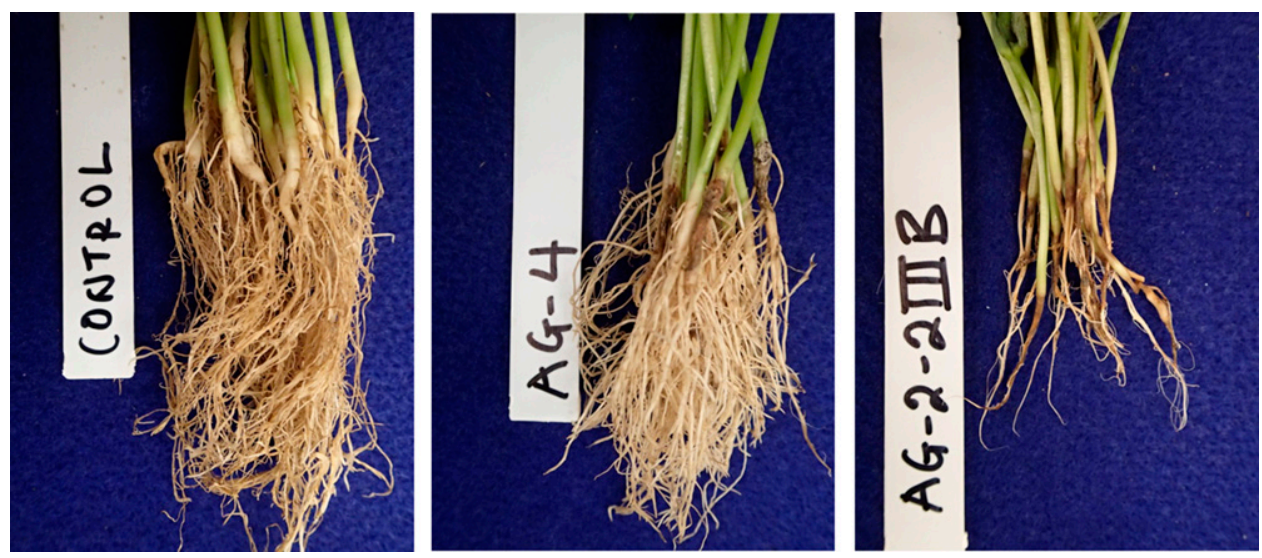

Fig. 6. Hypocotyl and root rot symptoms caused by Rhizoctonia solani anastomosis group (AG)-2-2IIIB and AG-4 on Williams 82 soybean. 
sp. AG-F isolates more closely with $R$. solani AG-4 isolates than with other Ceratobasidium spp. (Sharon et al. 2007). Also, the genetic relatedness between AG-F and $R$. solani AG-6 has been suggested based on hyphal anastomosis reactions (Yokoyama and Ogoshi 1986). Together, these observations indicate that BR represents a polyphyletic group and that further studies are required to clarify their phylogenetic relationship with $R$. solani.

From the greenhouse pathogenicity experiments on soybean, considerable variation in the aggressiveness among the different $R$. solani AG and other species of Rhizoctonia was observed. The most frequently recovered group, AG-2-2IIIB, was also the most aggressive on soybean roots and hypocotyls. The AG-2-2IIIB isolates also exhibited significant variability in their aggressiveness on soybean, and virulence was not correlated with isolate origin. Variability in aggressiveness of AG-2-2IIIB isolates has been reported previously (Dorrance et al. 2003; Muyolo et al. 1993a; Nelson et al. 1996). These observations highlight the importance of determining the aggressiveness of an isolate if the goal of the breeding program is to select for resistant soybean genotypes. The AG-4 isolates were not as aggressive as the AG-2-2IIIB isolates. Similar to what has been observed by other researchers (Fenille et al. 2002, 2003; Muyolo et al. 1993a), AG-4 isolates caused more severe symptoms on the hypocotyls while AG-2-2IIIB isolates caused more severe symptoms on the roots (Fig. 6). Although the five AG-4 isolates tested represented two homogenous groups (AG-4 HGI and AG-4 HGIII), there were no differences in aggressiveness among the five AG-4 isolates evaluated in the greenhouse. Disease symptoms produced by AG-7 and AG-11 isolates were comparable with those caused by the AG-4 isolates. This contradicts previous observations by other researchers, where these two AG were found to be less aggressive than AG-4 on soybean seedlings (Carling et al. 1994; Rothrock et al. 1993). The long-term coexistence with soybean in the absence of other major host plants may have played a role in expanding the host range of these two AG; however, because we did not evaluate the pathogenicity of isolates of AG-7 and AG-11 recovered outside of Illinois, it is impossible to validate our hypothesis. Pathogenicity tests did not implicate the recovered Ceratobasidium spp. and $R$. zeae as pathogens of soybean. BR and $R$. zeae generally are not considered pathogens of soybean, even though they have been recovered from soybean seedlings at different locations (Naito et al. 1993; Nelson et al. 1996). Isolates of certain CAG of BR have been shown to be pathogenic on a number of host crops (Burpee et al. 1980b; Kataria and Hoffmann 1988; Sneh et al. 1991) while those of $R$. zeae mostly attack corn and turfgrass species (Burpee and Martin 1992; Martin and Lucas 1984a; Sumner and Bell 1982; Voorhees 1934). Naito et al. (1993) identified isolates of AG-E from Indonesia as potential pathogens of soybean. However, the Ceratobasidium isolates evaluated in our greenhouse assays are members of CAG-2 (AG-A), suggesting that soybean is not a potential host to this AG. Although isolates of Ceratobasidium spp. and $R$. zeae produced little to no necrotic lesions on corn roots, we observed a significant reduction in dry root weight of plants inoculated with these groups compared with the noninoculated control. Our observations with these two species of Rhizoctonia suggest that root weight reduction may be due to the production of root growth inhibitory compounds.

Results of pathogenicity tests revealed that corn is a host to the AG that are pathogenic on soybean, especially AG-2-2IIIB, AG-4, and AG-11. The AG-4 and AG-2-2IIIB isolates were highly aggressive on corn, severely rotting both the crown and seminal roots. Isolates of AG-2-2IIIB are known to cause root rot of corn in the United States (Ohkura et al. 2009; Sumner and Bell 1982) and Europe (Buddemeyer et al. 2004; Ithurrart et al. 2004), and AG-4 isolates have been reported to produce root rot symptoms that are not as severe as those produced by AG-2-2IIIB isolates (Fenille et al. 2002; Muyolo et al. 1993a; Zhao et al. 2005). Because we tested only one isolate of AG-4, which belongs to HGI, we were unable to correlate HG types to virulence on corn or make conclusions regarding variation in aggressiveness of HG types of AG-4 on corn. Root damage caused by AG-11 isolates was mild and mostly restricted to the mesocotyl. The identification of corn as a susceptible host to the most aggressive AG on soybean indicates a high potential for inoculum build-up in the corn-soybean rotations in Illinois. Therefore, management practices that reduce inoculum build-up of these AG on farmers' fields deserve consideration in this region.

In summary, our work provides evidence for the association of a diverse group of Rhizoctonia spp. with soybean, with AG-2-2IIIB as the most predominant and aggressive group. Two groups (AG2-1 and AG-4 HGI) previously unidentified as part of the soybean seedling disease complex and two divergent groups of AG-7 were identified in this study. The susceptibility of corn to AG-2-2IIIB and other AG pathogenic on corn highlights the potential risks of the corn-soybean rotation, especially in areas where such AG are prevalent.

\section{Acknowledgments}

We thank the United Soybean Board and the North Central Soybean Research Program for financial support of this project; and K. Ames, K. Krausz, D. Pedersen, and U. Reuter-Carlson for technical assistance.

\section{Literature Cited}

Akaike, H. 1974. A new look at the statistical model identification. IEEE Trans. Autom. Control 19:716-723.

Altschul, S. F., Madden, T. L., Schäffer, A. A., Zhang, J., Zhang, Z., Miller, W., and Lipman, D. J. 1997. Gapped BLAST and PSI-BLAST: A new generation of protein database search programs. Nucleic Acids Res. 25:3389-3402.

American Soybean Association. 2015. Soy Stats 2015. U.S. Yield \& Production Production by State. Online publication. http://soystats.com/u-s-yield-productionproduction-by-state/

Anderson, N. A. 1982. The genetics and pathology of Rhizoctonia solani. Annu. Rev. Phytopathol. 20:329-347.

Anderson, N. A. 1984. Variation and heterokaryosis in Rhizoctonia solani. Pages 367-382 in: The Ecology and Physiology of the Fungal Mycelium. D. H. Jennings and A. D. M. Rayner, eds. Cambridge University Press, New York.

Baird, R. E., and Carling, D. E. 1995. First report of Rhizoctonia solani AG-7 in Indiana. Plant Dis. 79:321.

Baird, R. E., and Carling, D. E. 1997. First Report of Rhizoctonia solani AG-7 in Georgia. Plant Dis. 81:832.

Baird, R. E., Carting, D. E., and Mullinix, B. G. 1996. Characterization and comparison of isolates of Rhizoctonia solani AG-7 from Arkansas, Indiana, and Japan, and select AG-4 isolates. Plant Dis. 80:1421-1424.

Balali, G. R., Neate, S. M., Scott, E. S., Whisson, D. L., and Wicks, T. J. 1995. Anastomosis group and pathogenicity of isolates of Rhizoctonia solani from potato crops in South Australia. Plant Pathol. 44:1050-1057.

Balali, G. R., Whisson, D. L., Scott, E. S., and Neate, S. M. 1996. DNA fingerprinting probe specific to isolates of Rhizoctonia solani AG-3. Mycol. Res. 100:467-470.

Bandoni, R. J. 1979. Safranin O as a rapid nuclear stain for fungi. Mycologia 71: 873-874.

Barnes, J. S., Csinos, A. S., and Branch, W. D. 1990. Sensitivity of Rhizoctonia solani isolates to fungicides and evaluation of peanut cultivars to Rhizoctonia limb rot. Peanut Sci. 17:62-65.

Bolkan, H. A., and Ribeiro, W. R. C. 1985. Anastomosis groups and pathogenicity of Rhizoctonia solani isolates from Brazil. Plant Dis. 69:599-601.

Brenneman, T. B. 1996. Peanut diseases incited by Rhizoctonia species. Pages 315-320 in: Rhizoctonia Species: Taxonomy, Molecular Biology, Ecology, Pathology and Disease Control. B. Sneh, S. Jabaji-Hare, S. Neate, and G. Dijst, eds. Kluwer Academic Publishers, Dordrecht, The Netherlands.

Brunner, E., Domhof, S., and Langer, F. 2002. Nonparametric Analysis of Longitudinal Data in Factorial Experiments. John Wiley \& Sons, New York

Buddemeyer, J., Pfähler, B., Petersen, J., and Märländer, B. 2004. Genetic variation in susceptibility of maize to Rhizoctonia solani (AG 2-2IIIB)-symptoms and damage under field conditions in Germany. J. Plant Dis. Prot. 111:521-533.

Budge, G. E., Shaw, M. W., Lambourne, C., Jennings, P., Clayburn, R., Boonham, N., and McPherson, M. 2009. Characterization and origin of infection of Rhizoctonia solani associated with Brassica oleracea crops in the UK. Plant Pathol. 58:1059-1070.

Burpee, L., and Martin, B. 1992. Biology of Rhizoctonia species associated with turfgrasses. Plant Dis. 76:112-117

Burpee, L. L., Sanders, P. L., Cole, H., Jr., and Sherwood, R. T. 1980a Anastomosis groups among isolates of Ceratobasidium cornigerum and related fungi. Mycologia 72:689-701.

Burpee, L. L., Sanders, P. L., Cole, H., Jr., and Sherwood, R. T. 1980b. Pathogenicity of Ceratobasidium cornigerum and related fungi representing five anastomosis groups. Phytopathology 70:843-846.

Carling, D. E. 1996. Grouping in Rhizoctonia solani by hyphal anastomosis reaction. Pages 37-47 in: Rhizoctonia Species: Taxonomy, Molecular Biology, Ecology, Pathology and Disease Control. B. Sneh, S. Jabaji-Hare, S. Neate, and G. Dijst, eds. Kluwer Academic Publishers, Dordrecht, The Netherlands. 
Carling, D. E., Helm, D. J., and Leiner, R. H. 1990. In vitro sensitivity of Rhizoctonia solani and other multinucleate and binucleate Rhizoctonia to selected fungicides. Plant Dis. 74:860-863.

Carling, D. E., and Kuninaga, S. 1990. DNA Base sequence homology in Rhizoctonia solani Kühn: Inter- and intragroup relatedness of anastomosis group-9. Phytopathology 80:1362-1364.

Carling, D. E., Kuninaga, S., and Brainard, K. A. 2002. Hyphal anastomosis reactions, rDNA-internal transcribed spacer sequences, and virulence levels among subsets of Rhizoctonia solani anastomosis group-2 (AG-2) and AG-BI. Phytopathology 92:43-50.

Carling, D. E., Kuninaga, S., and Leiner, R. H. 1988. Relatedness within and among intraspecific groups of Rhizoctonia solani: A comparison of grouping by anastomosis and by DNA hybridization. Phytoparasitica 16:209-210.

Carling, D. E., Leiner, R. H., and Kebler, K. M. 1987. Characterization of a new anastomosis group (AG-9) of Rhizoctonia solani. Phytopathology 77:16091612 .

Carling, D. E., Pope, E. J., Brainard, K. A., and Carter, D. A. 1999. Characterization of mycorrhizal isolates of Rhizoctonia solani from an orchid, including AG-12, a new anastomosis group. Phytopathology 89:942-946.

Carling, D. E., Rothrock, C. S., MacNish, G. C., Sweetingham, M. W., Brainard, K. A., and Winters, S. W. 1994. Characterization of anastomosis group 11 (AG11) of Rhizoctonia solani. Phytopathology 84:1387-1393.

Dorrance, A. E., Kleinhenz, M. D., McClure, S. A., and Tuttle, N. T. 2003. Temperature, moisture, and seed treatment effects on Rhizoctonia solani root rot of soybean. Plant Dis. 87:533-538.

Doupnik, B. J. 1993. Soybean production and disease loss estimates for north central United States from 1989 to 1991. Plant Dis. 77:1170-1171.

Engelkes, C. A., and Windels, C. E. 1996. Susceptibility of sugar beet and beans to Rhizoctonia solani AG-2-2 IIIB and AG-2-2 IV. Plant Dis. 80:1413-1417.

Fenille, R. C., Ciampi, M. B., Kuramae, E. E., and Souza, N. L. 2003. Identification of Rhizoctonia solani associated with soybean in Brazil by rDNA-ITS sequences. Fitopatol. Bras. 28:413-419.

Fenille, R. C., De Souza, N. L., and Kuramae, E. E. 2002. Characterization of Rhizoctonia solani associated with soybean in Brazil. Eur. J. Plant Pathol. 108:783-792.

Flentje, N. T., Stretton, H. M., and McKenzie, A. R. 1967. Mutation in Thanatephorus cucumeris. Aust. J. Biol. Sci. 20:1173-1180.

Garbeva, P., Postma, J., van Veen, J. A., and van Elsas, J. D. 2006. Effect of aboveground plant species on soil microbial community structure and its impact on suppression of Rhizoctonia solani AG3. Environ. Microbiol. 8:233-246.

Gonzalez, D., Carling, D. E., Kuninaga, S., Vilgalys, R., and Cubeta, M. A. 2001. Ribosomal DNA systematics of Ceratobasidium and Thanatephorus with Rhizoctonia anamorphs. Mycologia 93:1138-1150.

González, D., Cubeta, M. A., and Vilgalys, R. 2006. Phylogenetic utility of indels within ribosomal DNA and $\beta$-tubulin sequences from fungi in the Rhizoctonia solani species complex. Mol. Phylogenet. Evol. 40:459-470.

Grosch, R., Schneider, J. H. M., and Kofoet, A. 2004. Characterization of Rhizoctonia solani anastomosis groups causing bottom rot in field-grown lettuce in Germany. Eur. J. Plant Pathol. 110:53-62.

Gudmestad, N. C., Stack, R. W., and Salas, B. 1989. Colonization of potato by Rhizoctonia solani as affected by crop rotation. Pages 147-252 in: Effects of Crop Rotation on Potato Production in the Temperate Zones. J. Vos, C. D. Van Loon, and G. J. Bollen, eds. Kluwer Academic Publishers, Dordrecht, The Netherlands.

Guillemaut, C., Edel-Hermann, V., Camporota, P., Alabouvette, C., RichardMolard, M., and Steinberg, C. 2003. Typing of anastomosis groups of Rhizoctonia solani by restriction analysis of ribosomal DNA. Can. J. Microbiol. 49:556-568

Herr, L. J. 1992. Characteristics of Rhizoctonia isolates associated with bottom rot of lettuce in organic soils in Ohio. Phytopathology 82:1046-1052.

Hua, G. K. H., Bertier, L., Soltaninejad, S., and Höfte, M. 2014. Cropping systems and cultural practices determine the Rhizoctonia anastomosis groups associated with Brassica spp. in Vietnam. PLoS One 9:e111750.

Hwang, S. F., Gossen, B. D., Conner, R. L., Chang, K. F., Turnbull, G. D., Lopetinsky, K., and Howard, R. J. 2007. Management strategies to reduce losses caused by Rhizoctonia seedling blight of field pea. Can. J. Plant Sci. $87: 145-155$

Ithurrart, M. E. F., Büttner, G., and Petersen, J. 2004. Rhizoctonia root rot in sugar beet (Beta vulgaris ssp. altissima): Epidemiological aspects in relation to maize (Zea mays) as a host plant. J. Plant Dis. Prot. 111:302-312.

Jones, R. K., and Belmar, S. B. 1989. Characterization and pathogenicity of Rhizoctonia spp. isolated from rice, soybean, and other crops grown in rotation with rice in Texas. Plant Dis. 73:1004-1010.

Jones, R. K., and Carling, D. E. 1999. Identification of Rhizoctonia solani AGUNK from rice and rice fields in Texas as AG-11. Plant Dis. 83:880.

Kataria, H. R., and Hoffmann, G. M. 1988. A critical review of plant pathogenic species of Ceratobasidium Rogers. J. Plant Dis. Prot. 95:81-107.

Kataria, H. R., Hugelshofer, U., and Gisi, U. 1991. Sensitivity of Rhizoctonia species to different fungicides. Plant Pathol. 40:203-211.

Ko, W. H., and Hora, F. K. 1971. A selective medium for the quantitative determination of Rhizoctonia solani in soil. Phytopathology 61:707-710.

Koenning, S. R., and Wrather, J. A. 2010. Suppression of soybean yield potential in the continental United States by plant diseases from 2006 to
2009. Online publication. Plant Health Prog. doi:10.1094/PHP-20101122-01-RS

Kronland, W. C., and Stanghellini, M. E. 1988. Clean slide technique for the observation of anastomosis and nuclear condition of Rhizoctonia solani. Phytopathology 78:820-822.

Kumar, S., Sivasithamparam, K., Gill, J. S., and Sweetingham, M. W. 1999. Temperature and water potential effects on growth and pathogenicity of Rhizoctonia solani AG-11 to lupin. Can. J. Microbiol. 45:389-395.

Kuninaga, S., Carling, D. E., Takeuchi, T., and Yokosawa, R. 2000. Comparison of rDNA-ITS sequences between potato and tobacco strains in Rhizoctonia solani AG-3. J. Gen. Plant Pathol. 66:2-11.

Kuninaga, S., Godoy-Lutz, G., and Yokosawa, R. 2002. rDNA-ITS nucleotide sequences analysis of Thanatephorus cucumeris AG-1 associated with web blight on common beans in Central America and Caribbean. Jpn. J. Phytopathol. 68:3-20.

Kuninaga, S., Natsuaki, T., Takeuchi, T., and Yokosawa, R. 1997. Sequence variation of the rDNA ITS regions within and between anastomosis groups in Rhizoctonia solani. Curr. Genet. 32:237-243.

Kuninaga, S., Sayama, A., and Yokosawa, R. 2007. Rhizoctonia solani strains associated with a leaf blight of tomato are classified into a new subgroup within AG-3 (Abstract in Japanese). Ann. Phytopathol. Soc. Jpn. 73:184

Kuninaga, S., and Yokosawa, R. 1984. DNA base sequence homology in Rhizoctonia solani Kuhn. V. Genetic relatedness within AG-6. Ann. Phytopathol. Soc. Jpn. 50: 346-352

Kuramae, E. E., Buzeto, A. L., Ciampi, M. B., and Souza, N. L. 2003. Identification of Rhizoctonia solani AG 1-IB in lettuce, AG 4 HG-I in tomato and melon, and AG 4 HG-III in broccoli and spinach, in Brazil. Eur. J. Plant Pathol. 109:391-395.

Lees, A. K., Cullen, D. W., Sullivan, L., and Nicolson, M. J. 2002. Development of conventional and quantitative real-time PCR assays for the detection and identification of Rhizoctonia solani AG-3 in potato and soil. Plant Pathol. 51: 293-302.

Liu, Z., and Sinclair, J. B. 1991. Isolates of Rhizoctonia solani anastomosis group 2-2 pathogenic to soybean. Plant Dis. 75:682-687.

Liu, Z. L., and Sinclair, J. B. 1992. Genetic diversity of Rhizoctonia solani anastomosis group 2. Phytopathology 82:778-787.

MacNish, G. C., and Sweetingham, M. W. 1993. Evidence that each Rhizoctonia bare patch is dominated by an individual zymogram group (ZG) of Rhizoctonia solani AG-8. Crop Pasture Sci. 44:1175-1194.

Martin, S. B., and Lucas, L. T. 1984a. Characterization and pathogenicity of Rhizoctonia spp. and binucleate Rhizoctonia-like fungus from turfgrass in North Carolina. Phytopathology 74:170-175.

Martin, S. B., Lucas, L. T., and Campbell, C. L. 1984b. Comparative sensitivity of Rhizoctonia solani and Rhizoctonia-like fungi to selected fungicides in vitro. Phytopathology 74:778-781.

Meyer, J. C., Wyk, R. J., and Phillips, A. J. L. 1990. Rhizoctonia leaf spot of tobacco in South Africa. Plant Pathol. 39:206-207.

Misawa, T., and Kuninaga, S. 2010. The first report of tomato foot rot caused by Rhizoctonia solani AG-3 PT and AG-2-Nt and its host range and molecula characterization. J. Gen. Plant Pathol. 76:310-319.

Mukou, H., Kagiwata, T., and Sueyama, K. 1975. Rot of cabbage by Rhizoctonia solani. Ann. Phytopathol. Soc. Jpn. 41:82.

Muyolo, N. G., Lipps, P. E., and Schmitthenner, A. F. 1993a. Anastomosis grouping and variation in virulence among isolates of Rhizoctonia solani associated with dry bean and soybean in Ohio and Zaire. Phytopathology 83:438-444.

Muyolo, N. G., Lipps, P. E., and Schmitthenner, A. F. 1993b. Reactions of dry bean, lima bean, and soybean cultivars to Rhizoctonia root and hypocotyl rot and web blight. Plant Dis. 77:234-238.

Naito, S., Mohamad, D., Nasution, A., and Purwanti, H. 1993. Soil-borne diseases and ecology of pathogens on soybean roots in Indonesia. Jpn. Agric. Res. Q. 26: 247-253.

Nakatomi, Y., and Kaneko, H. 1971. Ecology and control of leaf blight of tulip Plant Prot. Jpn. 25:191-194.

Neate, S. M., and Warcup, J. H. 1985. Anastomosis grouping of some isolates of Thanatephorus cucumeris from agricultural soils in South Australia. Trans. Br. Mycol. Soc. 85:615-620.

Nelson, B., Helms, T., Christianson, T., and Kural, I. 1996. Characterization and pathogenicity of Rhizoctonia from soybean. Plant Dis. 80:74-80.

Nicoletti, R., Lahoz, E., Kanematsu, S., Naito, S., and Contillo, R. 1999 Characterization of Rhizoctonia solani isolates from tobacco fields related to anastomosis groups 2-1 and BI (AG 2-1 and AG BI). J. Phytopathol. 147:71-77.

Ogoshi, A. 1972. Grouping of Rhizoctonia solani Kühn with hyphal anastomosis. Ann. Phytopathol. Soc. Jpn. 38:117-122_1.

Ogoshi, A. 1987. Ecology and pathogenicity of anastomosis and intraspecific groups of Rhizoctonia solani Kuhn. Annu. Rev. Phytopathol. 25:125-143.

Ogoshi, A., Oniki, M., Araki, T., and Ui, T. 1983. Anastomosis groups of binucleate Rhizoctonia in Japan and North America and their perfect states. Trans. Mycol. Soc. Jpn. 24:79-87.

Ohkura, M., Abawi, G. S., Smart, C. D., and Hodge, K. T. 2009. Diversity and aggressiveness of Rhizoctonia solani and Rhizoctonia-like fungi on vegetables in New York. Plant Dis. 93:615-624

Parmeter, J. R., Sherwood, R. T., and Platt, W. D. 1969. Anastomosis grouping among isolates of Thanatephorus cucumeris. Phytopathology 59:12701278. 
Paulitz, T. C., Okubara, P. A., and Schillinger, W. F. 2006. First report of dampingoff of canola caused by Rhizoctonia solani AG 2-1 in Washington State. Plant Dis. 90:829.

Paulitz, T. C., and Schroeder, K. L. 2005. A new method for the quantification of Rhizoctonia solani and R. oryzae from Soil. Plant Dis. 89:767-772.

Ploetz, R. C., Mitchell, D. J., and Gallaher, R. N. 1985. Characterization and pathogenicity of Rhizoctonia species from a reduced-tillage experiment multicropped to rye and soybean in Florida. Phytopathology 75:833-839.

Pope, E. J., and Carter, D. A. 2001. Phylogenetic placement and host specificity of mycorrhizal isolates belonging to AG-6 and AG-12 in the Rhizoctonia solani species complex. Mycologia 93:712-719.

Posada, D., and Crandall, K. A. 1998. Modeltest: Testing the model of DNA substitution. Bioinformatics 14:817-818.

Priyatmojo, A., Escopalao, V. E., Tangonan, N. G., Pascual, C. B., Suga, H., Kageyama, K., and Hyakumachi, M. 2001. Characterization of a New Subgroup of Rhizoctonia solani anastomosis group 1 (AG-1-ID), causal agent of a necrotic leaf spot on Coffee. Phytopathology 91:1054-1061.

Richter, H., and Schneider, R. 1953. Untersuchungen zur morphologischen und biologischen Differenzierung von Rhizoctonia solani K. Phytopathol. Z. 20: 167-226.

Rizvi, S. S. A., and Yang, X. B. 1996. Fungi associated with soybean seedling disease in Iowa. Plant Dis. 80:57-60.

Roberts, F. A., and Sivasithamparam, K. 1986. Identity and pathogenicity of Rhizoctonia spp. associated with bare patch disease of cereals at a field site in Western Australia. Neth. J. Plant Pathol. 92:185-195.

Ronquist, F., and Huelsenbeck, J. P. 2003. MrBayes 3: Bayesian phylogenetic inference under mixed models. Bioinformatics 19:1572-1574.

Rothrock, C. S. 1996. Cotton diseases incited by Rhizoctonia solani. Pages 269-277 in: Rhizoctonia Species: Taxonomy, Molecular Biology, Ecology, Pathology and Disease Control. B. Sneh, S. Jabaji-Hare, S. Neate, and G. Dijst, eds. Kluwer Academic Publishers, Dordrecht, The Netherlands.

Rothrock, C. S., Winters, S. A., Kinney, P. M., and Carling, D. E. 1993. Occurrence of Rhizoctonia solani (Thanatephorus cucumeris) AG-7 in Arkansas. Plant Dis. 77:1262.

Salazar, O., Julián, M. C., Hyakumachi, M., and Rubio, V. 2000. Phylogenetic grouping of cultural types of Rhizoctonia solani AG 2-2 based on ribosomal ITS sequences. Mycologia 92:505-509.

Salazar, O., Schneider, J. H. M., Julián, M. C., Keijer, J., and Rubio, V. 1999. Phylogenetic subgrouping of Rhizoctonia solani AG-2 isolates based on ribosomal ITS sequences. Mycologia 91:459-467.

Schmitthenner, A. F., and Hilty, J. W. 1962. A method for studying post emergence seedling root rot. Phytopathology 52:177-178.

Schneider, J. H. M., Schilder, M. T., and Dijst, G. 1997. Characterization of Rhizoctonia solani AG 2 isolates causing bare patch in field grown tulips in the Netherlands. Eur. J. Plant Pathol. 103:265-279.

Shah, D. A., and Madden, L. V. 2004. Nonparametric analysis of ordinal data in designed factorial experiments. Phytopathology 94:33-43.

Sharma-Poudyal, D., Paulitz, T. C., Porter, L. D., and du Toit, L. J. 2015. Characterization and pathogenicity of Rhizoctonia and Rhizoctonia-like spp. from pea crops in the Columbia Basin of Oregon and Washington. Plant Dis. 99:604-613.

Sharon, M., Freeman, S., Kuninaga, S., and Sneh, B. 2007. Genetic diversity, anastomosis groups and virulence of Rhizoctonia spp. from strawberry. Eur. J. Plant Pathol. 117:247-265.

Sharon, M., Kuninaga, S., Hyakumachi, M., Naito, S., and Sneh, B. 2008. Classification of Rhizoctonia spp. using rDNA-ITS sequence analysis supports the genetic basis of the classical anastomosis grouping. Mycoscience 49:93-114

Sharon, M., Kuninaga, S., Hyakumachi, M., and Sneh, B. 2006. The advancing identification and classification of Rhizoctonia spp. using molecular and biotechnological methods compared with the classical anastomosis grouping. Mycoscience 47:299-316.

Sneh, B., Burpee, L., and Ogoshi, A. 1991. Identification of Rhizoctonia Species. American Phytopathological Society, St. Paul, MN
Spurlock, T. N., Rothrock, C. S., Monfort, W. S., and Griffin, T. W. 2016. The distribution and colonization of soybean by Rhizoctonia solani AG11 in fields rotated with rice. Soil Biol. Biochem. 94:29-36.

Stevens Johnk, J., Jones, R. K., Shew, H. D., and Carling, D. E. 1993 Characterization and populations of Rhizoctonia solani AG-3 from potato and tobacco. Phytopathology 83:854-858.

Stodart, B. J., Harvey, P. R., Neate, S. M., Melanson, D. L., and Scott, E. S. 2007. Genetic variation and pathogenicity of anastomosis group 2 isolates of Rhizoctonia solani in Australia. Mycol. Res. 111:891-900.

Sumner, D. R., and Bell, D. K. 1982. Root diseases induced in corn by Rhizoctonia solani and Rhizoctonia zeae. Phytopathology 72:86-91.

Sweetingham, M. W. 1989. Fungi associated with root and hypocotyl diseases of seedling lupins in Western Australia. Crop Pasture Sci. 40:781-789.

Swofford, D. L. 1998. PAUP*: Phylogenetic Analysis Using Parsimony (and other methods). Sinauer Associates, Sunderland, MA.

Tachibana, H. 1968. Rhizoctonia solani root rot epidemic of soybeans in Central Iowa 1967. Plant Dis. Rep. 52:613-614.

Tachibana, H., Jowett, D., and Fehr, W. R. 1971. Determination of losses in soybeans caused by Rhizoctonia solani. Phytopathology 61:1444-1446.

Tamura, K., Stecher, G., Peterson, D., Filipski, A., and Kumar, S. 2013. MEGA6: Molecular evolutionary genetics analysis version 6.0. Mol. Biol. Evol. 30: 2725-2729.

Vilgalys, R., and Cubeta, M. A. 1994. Molecular systematics and population biology of Rhizoctonia. Annu. Rev. Phytopathol. 32:135-155.

Voorhees, R. K. 1934. Sclerotial rot of corn caused by Rhizoctonia zeae, n. sp. Phytopathology 24:1290-1303.

Watanabe, B., and Matsuda, A. 1966. Studies on the grouping of Rhizoctonia solani Kühn pathogenic to upland crops. Designated Experiment (Plant Diseases and Insect Pests) No. 7, Agriculture, Forestry, and Fisheries Research Council and Ibaraki Agricultural Experiment Station (In Japanese with English summary).

Wharton, P., Kirk, W., Berry, D., and Snapp, S. 2006. Rhizoctonia stem canker and black scurf of potato. Online publication. Department of Plant Pathology, Michigan State University. http://msue.anr.msu.edu/resources/potato_diseases_ rhizoctonia stem canker_and black scurf e2994

White, T. J., Bruns, T., Lee, S., and Taylor, J. 1990. Amplification and direct sequencing of fungal ribosomal RNA genes for phylogenetics. Pages 315-322 in: PCR Protocols: A Guide to Methods and Applications. M. A Innis, D. H. Gelfand, J. J. Sninsky, and T. J. T. J. White, eds. Academic Press, Inc., New York.

Windels, C. E., Kuznia, R. A., and Call, J. 1997. Characterization and pathogenicity of Thanatephorus cucumeris from sugar beet in Minnesota. Plant Dis. 81:245-249.

Windels, C. E., and Nabben, D. J. 1989. Characterization and pathogenicity of anastomosis groups of Rhizoctonia solani isolated from Beta vulgaris. Phytopathology 79:83-88

Woodhall, J. W., Lees, A. K., Edwards, S. G., and Jenkinson, P. 2007 Characterization of Rhizoctonia solani from potato in Great Britain. Plant Pathol. 56:286-295.

Wrather, J. A., and Koenning, S. R. 2006. Estimates of disease effects on soybean yields in the United States 2003 to 2005. J. Nematol. 38:173-180.

Yamamoto, D. T., and Uchida, J. Y. 1982. Rapid nuclear staining of Rhizoctonia solani and related fungi with acridine orange and with safranin O. Mycologia $74: 145-149$

Yang, X. B., Berggren, G. T., and Snow, J. P. 1990. Seedling infection of soybean by isolates of Rhizoctonia solani AG-1, causal agent of aerial blight and web blight of soybean. Plant Dis. 74:485-488.

Yokoyama, K., and Ogoshi, A. 1986. Studies on hyphal anastomosis of Rhizoctonia solani. IV. Observation of imperfect fusion by light and electron microscopy. Trans. Mycol. Soc. Jpn. 27:399-413.

Zhao, G., Ablett, G. R., Anderson, T. R., Rajcan, I., and Schaafsma, A. W. 2005. Anastomosis groups of Rhizoctonia solani associated with soybean root and hypocotyl rot in Ontario and resistance of accession PI 442031 to different anastomosis groups. Can. J. Plant Pathol. 27:108-117. 